\title{
Conversion of marginal land into switchgrass conditionally accrues soil carbon but reduces methane consumption
}

\author{
Colin T. Bates ${ }^{1,2} \cdot$ Arthur Escalas $\mathbb{D}^{3} \cdot$ Jialiang Kuang $\mathbb{D}^{1} \cdot$ Lauren Hale $^{4} \cdot$ Yuan Wang $^{5} \cdot$ Don Herman ${ }^{6,7}$. \\ Erin E. Nuccio $\mathbb{1}^{6} \cdot$ Xiaoling Wan ${ }^{8} \cdot$ Amrita Bhattacharyya ${ }^{6,9} \cdot$ Ying $\mathrm{Fu}^{1,2} \cdot$ Renmao Tian $\mathbb{1}^{1,2} \cdot$ Gangsheng Wang $\mathbb{D}^{1,2} \cdot$ \\ Daliang Ning $\mathbb{D}^{1,2} \cdot$ Yunfeng Yang $\mathbb{1}^{10} \cdot$ Liyou $\mathrm{Wu}^{1,2} \cdot$ Jennifer Pett-Ridge $\mathbb{D}^{6} \cdot$ Malay Saha $^{5} \cdot$ Kelly Craven ${ }^{5} \cdot$ \\ Eoin L. Brodie $\mathbb{1}^{7,9} \cdot$ Mary Firestone ${ }^{7,9} \cdot$ Jizhong Zhou $\mathbb{1}^{1,2,9,10}$
}

Received: 28 May 2020 / Revised: 15 January 2021 / Accepted: 27 January 2021 / Published online: 1 July 2021

This is a U.S. government work and not under copyright protection in the U.S.; foreign copyright protection may apply 2021

\begin{abstract}
Switchgrass is a deep-rooted perennial native to the US prairies and an attractive feedstock for bioenergy production; when cultivated on marginal soils it can provide a potential mechanism to sequester and accumulate soil carbon (C). However, the impacts of switchgrass establishment on soil biotic/abiotic properties are poorly understood. Additionally, few studies have reported the effects of switchgrass cultivation on marginal lands that have low soil nutrient quality (N/P) or in areas that have experienced high rates of soil erosion. Here, we report a comparative analyses of soil greenhouse gases (GHG), soil chemistry, and microbial communities in two contrasting soil types (with or without switchgrass) over 17 months (1428 soil samples). These soils are highly eroded, 'Dust Bowl' remnant field sites in southern Oklahoma, USA. Our results revealed that soil C significantly increased at the sandy-loam (SL) site, but not at the clay-loam (CL) site. Significantly higher $\mathrm{CO}_{2}$ flux was observed from the CL switchgrass site, along with reduced microbial diversity (both alpha and beta). Strikingly, methane $\left(\mathrm{CH}_{4}\right)$ consumption was significantly reduced by an estimated 39 and $47 \%$ at the SL and CL switchgrass sites, respectively. Together, our results suggest that soil C stocks and GHG fluxes are distinctly different at highly degraded sites when switchgrass has been cultivated, implying that carbon balance considerations should be accounted for to fully evaluate the sustainability of deep-rooted perennial grass cultivation in marginal lands.
\end{abstract}

Supplementary information The online version contains supplementary material available at https://doi.org/10.1038/s41396021-00916-y.

Jizhong Zhou

jzhou@ou.edu

1 The Institute for Environmental Genomics, University of Oklahoma, Norman, OK, USA

2 Department of Microbiology and Plant Biology, and School of Civil Engineering and Environmental Sciences, University of Oklahoma, Norman, OK, USA

3 MARBEC, University of Montpellier, Montpellier, France

4 USDA, Agricultural Research Service, San Joaquin Valley Agricultural Sciences Center, Parlier, CA, USA

5 Noble Research Institute, Ardmore, OK, USA

\section{Introduction}

Taking place over three waves during the 1930s, the American 'Dust Bowl' was a catastrophic ecological disaster that brought severe drought and dust storms to the central prairies of the US and affected roughly 40 million hectares of land [1-3]. These climatic events, combined

6 Physical and Life Sciences Directorate, Lawrence Livermore National Laboratory, Livermore, CA, USA

7 Department of Environmental Science, Policy and Management, University of California, Berkeley, CA, USA

8 The Key Laboratory of Aquatic Biodiversity and Conservation of the Chinese Academy of Sciences; Institute of Hydrobiology, Chinese Academy of Sciences, Wuhan, China

9 Earth and Environmental Sciences Area, Lawrence Berkeley National Laboratory, Berkeley, CA, USA

10 State Key Joint Laboratory of Environment Simulation and Pollution Control, School of Environment, Tsinghua University, Beijing, China 
with many years of poor land management and soil cultivation, exacerbated topsoil erosion, creating many 'marginal' lands of low soil nutrient quality, notably across Oklahoma and the Southwestern USA (Texas, Kansas, Colorado, and New Mexico). Since then, many of these sites have remained suboptimal for agricultural development. It has been suggested that widespread cultivation of deep-rooted perennial grasses may aid in soil restoration at these sites, while also offering further economic benefits to farmers in the form of cellulosic feedstocks for bioenergy production [4]. It is estimated that 15 million hectares of arable land would need to be converted into biofuel crops to meet the US Department of Energy's plan to replace $30 \%$ of transportation fossil fuels with biofuels by 2030 [5, 6]. An estimated $11 \%$ of the contiguous USA is considered nutrient-poor or 'marginal' land [7] and currently represents an under-utilized resource that may be well suited for cultivation of switchgrass or other deep-rooted perennials [8].

Switchgrass (Panicum virgatum L.), a tall perennial deep-rooted grass native to the Central North American Plains, is a well-studied bioenergy crop, and thought to be suitable for large-scale cultivation in the USA [9]. Switchgrass may even be implemented more broadly as it has been projected to grow favorably in numerous regions globally, both with and without irrigation [10]. This enthusiasm stems from switchgrass' high productivity even on lowquality soils unfit for traditional row-crop agriculture, with little to no additional inputs [11]. Long-term cultivation experiments suggest that switchgrass can provide a net input of $\mathrm{C}$ into soil [4, 12, 13]. Therefore, large-scale switchgrass cultivation may help to simultaneously offset GHG emissions and improve soil quality through C sequestration at nutrient-poor sites [14]. Switchgrass is also known to be highly drought tolerant [15] and can prevent topsoil erosion owing to its high root biomass, which increases the surface area for exudation, and can further improve soil $\mathrm{C}$ stability and aggregate formation [16, 17]. Like other perennial crops, switchgrass has been broadly associated with increases in soil $\mathrm{C}$ at many experimental sites across the central Great American Plains [18-20]. However, only a few studies have evaluated switchgrass cultivation at sites with low soil $\mathrm{N}, \mathrm{C}$, or $\mathrm{P}$ contents or in marginal lands that have experienced high rates of topsoil erosion [4, 21]. Thus, we currently have a very limited understanding of how switchgrass row-crop systems in nutrient-poor marginal lands can affect (i) soil geochemical composition, (ii) soil microbial diversity, and (iii) overall ecosystem functionality, specifically GHG fluxes.

Potential $\mathrm{C}$ accrual due to increased root inputs may be offset by higher soil $\mathrm{CO}_{2}$ production arising from stimulated microbial C mineralization, the so-called 'rhizosphere priming' effect [22]. Thus, while the total amount of soil organic carbon (SOC) may increase, the $\mathrm{C}$ input by switchgrass along a depth profile may also prime the degradation of preexisting SOC by the indigenous soil microbial community [23, 24]. Regulation of this priming response depends on the mineral composition [25], nutrient content [26], and microorganism present [27]. Therefore, to evaluate the carbon cycle benefits of deep-rooted perennials in marginal lands, it is essential to assess not only the balance of C-based GHG fluxes $\left(\mathrm{CO}_{2}\right.$ and $\left.\mathrm{CH}_{4}\right)$ but also other GHG (such as $\mathrm{N}_{2} \mathrm{O}$ ) and changes in soil microbiomes.

Because soil microorganisms are critical drivers of soil nutrient cycling, understanding plant-microbe interactions during switchgrass cultivation could inform land management strategies that promote soil nutrient acquisition (e.g., nitrogen fixation) and recycling, while reducing $\mathrm{GHG}$ emissions. A recent review of switchgrass-associated microbiomes suggests that mycorrhizal fungi, associated $\mathrm{N}$-fixing bacteria, and fungal endophytes play particularly key roles in increasing switchgrass biomass, providing a substantial portion of the plant's nitrogen demand, and improving drought tolerance [28]. By examining the microbial diversity and associated functional processes of switchgrass-influenced systems, prior research has revealed some of the mechanisms underlying the enhancement of ecosystem services such as $\mathrm{C}$ sequestration, soil fertility, and regulation of GHG emissions [5, 29-34]. For instance, it has been shown that $\mathrm{N}$ fertilization, at least at some sites, did not increase soil-surface carbon dioxide $\left(\mathrm{CO}_{2}\right)$ emissions despite promoting above- $[35,36]$ and below-ground biomass [37]. However, the relative impact of methane $\left(\mathrm{CH}_{4}\right)$ emissions during switchgrass establishment at highly eroded sites is not yet fully understood [38-40]. Additionally, the ecological consequences of land conversion, its impact on soil microbial diversity, and functionality, as well as the overall sustainability of switchgrass cultivation in low-quality soils, remain to be demonstrated.

In grasslands and agricultural systems, above (i.e., plant) and below (i.e., microbial) ground biodiversity [41] and biomass [42, 43] are related, and edaphic conditions can influence these relationships. A meta-analysis of temperate grasslands suggests a correlation between plant and bacterial beta diversity but not alpha diversity [44]. Previous studies of the microbiomes of monoculture agroecosystems have revealed differences in nitrogen-fixing bacterial communities [45], seasonal dynamics [46], and core microbiome members between different plant species [47]. Therefore, in the transition from an annual plant species to a monoculture perennial crop, we expect a decrease of both alpha and beta microbial diversity.

In this study, we monitored the below-ground microbiological and chemical impacts of switchgrass establishment and consequences for soil GHG emissions over two consecutive growing seasons ( $n=17$ months) in two nutrient-poor ( $\mathrm{N}$ and $\mathrm{P}$ ) field sites with low $\mathrm{C}$ content in 
southern Oklahoma (designated SL and CL for their sandyloam soil and clay-loam soil texture, respectively). We compared soil belowground (root) productivity, chemistry (C, N, and P), soil GHG fluxes $\left(\mathrm{CO}_{2}, \mathrm{CH}_{4}\right.$, and $\left.\mathrm{N}_{2} \mathrm{O}\right)$, and microbial community composition at each site with switchgrass or without switchgrass (natural fallow plots). We hypothesize that the following trends would be observed in the field plots with switchgrass: (i) increased topsoil $\mathrm{C}$ concentrations over time; (ii) $\mathrm{CO}_{2}$ production increases, with $\mathrm{CH}_{4}$ emission and $\mathrm{N}_{2} \mathrm{O}$ fluxes remaining relatively stable; and (iii) the microbial community would be altered during establishment and both species richness and beta diversity would decrease over time.

\section{Methods}

\section{Field site, soil sampling, and root biomass estimation}

Samples were collected from two sites in southern Oklahoma, a SL site near the Texas border $\left(33.881715^{\circ} \mathrm{N}\right.$, $\left.-97.275167^{\circ} \mathrm{W}\right)$ and a CL site in Ardmore $\left(34.172100^{\circ} \mathrm{N}\right.$, $-97.07953^{\circ} \mathrm{W}$ ) (Table S1). Prior to our experiment, the SL field site experienced crop rotation between small grains (wheat, rye, oat, and triticale) in the winter season and soybeans in the summer. Soybean was terminated before seed set to prepare the land for small grain planting as a cover crop. At the CL site, Bermuda grass was the dominant plant cover for at least 20 years prior to our study. These sites were selected for their low soil nutrient content $(\mathrm{N}$ and P) and their history of topsoil erosion.

In the summer of 2016, two plots were established at each site, a switchgrass field plot $(27 \times 22 \mathrm{~m})$ containing 500 genetically distinct individuals of the lowland Alamo variety with a $1 \mathrm{~m}$ spacing between plants and a corresponding fallow plot $(27 \times 22 \mathrm{~m})$ (Fig. S1a, b). All plots were tilled to $30 \mathrm{~cm}$ before the start of the experiment, and then planted with switchgrass seedlings with $1 \mathrm{~m}$ spacing. Switchgrass plots were sustainably managed, without any chemical fertilizers, herbicides, or watering. Fallow plots were allowed to undergo a natural succession of grasses and weeds over the time course of the experiment and served as controls to compare the dynamics in soil carbon, trace gas fluxes, and microbial community composition with the switchgrass treatment. In November 2016, a survey was conducted to determine the vegetative cover of the two fallow plots. The SL fallow surface was mostly composed of bare soil $(\sim 52 \%)$; plant litter $(\sim 31 \%)$ and annual forbs $(\sim 17 \%)$ covered the rest of the plot. The CL fallow surface was dominated by annual grass species $(\sim 86 \%)$, annual forbs $(\sim 2 \%)$ and bare soil $(\sim 1 \%)$ covering the remaining surface of the plot. Common plant genera at both fallow sites included the following: Oxalis, Dichanthelium, Cynodon, Brassica, Lamium, Trifolium, Cyperus, Geranium, Erigeron, Conyza, and Digitaria.

At each plot, to allow GHG measurements, 21 PVC collars (diameter $23.63 \times 12.8 \mathrm{~cm}$ height) (Fig. S1c) were embedded $8 \mathrm{~cm}$ into the soil and placed in a cross design across the field with five collars extending in each cardinal direction from a central origin collar at the plot center. After trace gas measurement from each collar, two soil cores $(0-20 \mathrm{~cm}$ in depth) were taken from within a $20 \mathrm{~cm}$ radius of each collar (Fig. S1d), thoroughly mixed, and separated into two aliquots, one for geochemical analyses and one for DNA extraction. Sampling flags were placed to prevent re-sampling the same location twice, and each core was filled by topsoil taken from outside the plot. All soil samples were immediately stored on dry ice, transported back to the lab in less than $5 \mathrm{~h}$, and stored at either $5{ }^{\circ} \mathrm{C}$ for geochemical analyses or $-80{ }^{\circ} \mathrm{C}$ for DNA extraction.

In May 2017, the total belowground root biomass was estimated using a method accounting for differences in root density between the plants in each row [48]. Briefly, six pairs of plants were selected, and a transect consisting of four $0-1 \mathrm{~m}$ cores was performed between each pair of plants (Fig. S2a). The two cores at the end of the transect represent the root density 'with-in' rows, and the two middle cores represent the root density of the 'between-rows'. Each core was divided into five $20 \mathrm{~cm}$ 'slices' of soil. For each depth, roots were collected by sieving and soaking the soil in water, before being dried and weighted. For fallow plots, four randomly assigned $1 \mathrm{~m}^{2}$ subplots were selected, in which a four $0-1 \mathrm{~m}$ soil cores transect was collected (Fig. S2b). No roots were detected from fallow soil cores below $60 \mathrm{~cm}$ depth.

\section{Soil geochemistry, pH, and moisture}

Soil $\mathrm{pH}$, moisture, total soil $\mathrm{C}$ and $\mathrm{N}$, plant-available $\mathrm{P}$, nitrate $\left(\mathrm{NO}_{3}\right)$, and ammonium $\left(\mathrm{NH}_{4}\right)$ pools were measured according to standard methods [49]. Briefly, $10 \mathrm{~g}$ of soil was placed into a $50 \mathrm{ml}$ tube with distilled $\mathrm{H}_{2} \mathrm{O}$ added to the $50 \mathrm{ml}$ fill line. Tubes were gently shaken for $30 \mathrm{~min}$ and given an hour to settle before $\mathrm{pH}$ measurement using a $\mathrm{pH}$ probe (Acccumet excel XL15 pH meter, Fisher Scientific, Hampton NH, USA). Soil moisture was determined by a gravimetric drying protocol that dried $>5 \mathrm{~g}$ of soil for one week at $>60^{\circ} \mathrm{C}$ before re-weighing to establish the percent of water lost. To determine other soil geochemical parameters, soil samples were dried in an oven at $60{ }^{\circ} \mathrm{C}$ for a week followed by sieving to remove unwanted material with a $4 \mathrm{~mm}$ sieve. Soil samples were then shipped seasonally to the Oklahoma State University (OSU) soil testing lab where Mehlich III extractions (to quantify the plant 
available $\mathrm{P}$ in the soil) and KCL extractions (to determine $\mathrm{NH}_{4}$ and $\mathrm{NO}_{3}$ concentrations) were performed and total soil $\mathrm{C} / \mathrm{N}$ amounts were measured via dry combustion (LECO corporation, St. Joseph MI, USA). To establish initial conditions, 3 replicate 2-meter soil pits were dug at each site prior to switchgrass planting, and sampled every $2 \mathrm{~cm}$ (Table S1). Soil chemical analyses were conducted on airdried soils at the Oregon State University Central Analytical Laboratory in Corvallis OR. Particle size analysis (sand/silt/ clay) was conducted on $40 \mathrm{~g}$ of soil using the hydrometer method [50]. $\mathrm{pH}$ and electrical conductivity (EC) were determined in a 1:1 soil/water ratio [51]. Total $\mathrm{C}$ and $\mathrm{N}$ were determined by combustion and a thermal conductivity detector [52]. Loss on ignition organic matter was measured after treatment in a muffle furnace [53]. Total P content was determined by digestion with nitric acid; extracts were analyzed by Inductively Coupled Plasma Atomic Emission Spectrometry (ICP-AES) [54]. Bioavailable P was determined using the Bray and Olsen methods for acidic to neutral $\mathrm{pH}$ soils [55-57]. Organic $\mathrm{P}$ was measured on $2 \mathrm{~g}$ soil extracted with $\mathrm{NaOH}-E D T A$ [58], amorphous $\mathrm{P}$ by ammonium-oxalate extraction [59], and crystalline $\mathrm{P}$ by citrate-dithionite extraction [60].

\section{Environmental parameters}

Daily environmental data for 21 different environmental variables (at 5 to 15-min resolution) were obtained from two weather monitoring stations of the Oklahoma MESONET network (http://mesonet.org/) closest to the field sites (Ardmore and Burneyville, located $1.43 \mathrm{~km}$ and $2.3 \mathrm{~km}$ from CL and SL, respectively). Variables used included air temperature, bare soil temperature, covered soil temperature, atmospheric pressure, relative humidity, and precipitation (Tables S2 and S3).

\section{Trace gas fluxes}

$\mathrm{CO}_{2}, \mathrm{CH}_{4}$, and $\mathrm{N}_{2} \mathrm{O}$ fluxes were measured monthly via cavity ring-down spectrometry using a Picarro G2508 analyzer (Picarro, Santa Clara, CA, U.S.A.). Measurements were taken continuously every $2 \mathrm{~s}$ from a total of $6 \mathrm{~min}$ per collar, to obtain gas concentrations in parts per million. Raw data from each gas were separated and then manually inspected to remove the beginning and the end of the measurements, which are often influenced by the pushing/pulling of the gas chamber (volume of the chamber + collar $=$ $7917 \mathrm{~cm}^{3}$ ). Then three models (linear, quadratic, and exponential) were fitted for each sample and gas species to characterize the variation of gas concentrations across time and the 'best model' was selected based on AIC scores. Flux estimations for each of the gases were then calculated using the following equation [61]:

$$
F=\frac{d c}{d t} \cdot \frac{P V}{A \cdot R(273.15+T)} \times 3600
$$

Where $\frac{d c}{d t}$ is the slope of the best fit model at $t=0, V$ is the chamber volume $(\mathrm{L}), A$ is the chamber area $\left(\mathrm{m}^{2}\right), R$ is the gas constant in $\mathrm{Latm} \mathrm{K}^{-1} \mathrm{~mol}^{-1}$, and $T$ is the temperature in Celsius, when the chamber pressure is assumed to be equal to $1 \mathrm{~atm}$. The 3600 factor is included to convert the flux to hourly values. For $\mathrm{CO}_{2}$ fluxes, $F$ was then divided by 1000 to obtain the units of millimoles per $\mathrm{m}^{2}$ per hour.

\section{Soil DNA extractions, microbial community sequencing and analysis}

All molecular biology procedures and DNA sequencing were performed at the Institute for Environmental Genomics (IEG, University of Oklahoma, USA). A freeze grinding method [62] was combined with the Powersoil DNA extraction kit (Qiagen, Venlo, Netherlands) to extract DNA from a total of 1428 soil samples, which yielded soil DNA of both high quantity and quality. For microbial community profiling, a two-step PCR method [63] was used for amplification of the V4 region of the bacterial $16 \mathrm{~S}$ rRNA gene using the 515 F, 5'-GTGCCAGCMGCCGC GGTAA-3' and 806 R, 5'-GGACTACHVGGGTWTCTAA $\mathrm{T}-3^{\prime}$ primers. Sequencing of the $16 \mathrm{~S}$ rRNA gene amplicons was conducted on the Illumina Mi-Seq DNA sequencing platform (Illumina Inc., San Diego, CA, U.S.A.). Amplicon sequence data were analyzed using an internal pipeline known as the Amplicon Sequencing Analysis Pipeline [64] (ASAP, version 1.4). MiSeq sequences were quality checked with FastQC (version 0.11.5), pair-end sequences were merged based on their $3^{\prime}$ overlap using PEAR (version 0.9 .10 ) with a quality score cutoff set to 20 , and assembly length between $200-400$ with the minimum overlap length set to $50 \mathrm{bp}$. The program split_libraries_fastq.py from the QIIME package [65] (version 1.9.1) was used to assign reads to each sample (demultiplexing) based on the barcodes for each individual sample with a maximum allowed barcode error of 0 and the trimming quality score set to 20 . Primer sequences were then trimmed and removed. Sequences from multiple split libraries were merged. Dereplication was performed by USEARCH [66] (version 9.2.64) using the command fastx_uniques (utilizing the size-out option for sequence abundance output). Operational Taxonomic Units (OTUs) were clustered using UPARSE, with the OTU identity threshold set to 0.97 and the singletons/chimeric sequences removed [67]. An OTU table was generated by the command -usearch_global in USEARCH. Each representative sequence for each OTU 
was classified with the RDP Classifier [68] (16 S: training set 16, June 2016) with the confidence cutoff set to 0.8 . OTUs in the $16 \mathrm{~S}$ sequence reads assigned to Chloroplast at the Order level were removed. Representative sequences for each OTU were used to construct a phylogenetic tree. Sequences were then aligned using MAFFT [69] (version 3.8.31) and alignments were filtered using Gblocks [70] (version $0.91 \mathrm{~b}$ ) with the options $-\mathrm{t}=\mathrm{d},-\mathrm{b} 4=3$ and $-\mathrm{b} 5=\mathrm{h}$. FastTree [71] was used for constructing the phylogenetic tree using the filtered alignments. The phylogenetic tree and OTU tables were used to calculate alpha diversity (phylogenetic based indexes) and beta diversity (UniFrac distance) using programs packaged in QIIME [72] and R [73].

\section{Statistical analyses}

All analyses were conducted using $\mathrm{R}$ statistical software [73] (3.4.4) and figures were produced using the package ggplot2 [74]. Data normality was tested using the Shapiro test. We tested for differences in GHG flux and microbial alpha diversity between plots using linear mixed models to correct for repeated measurements (i.e., collars within plots) and to analyze the data over time (R package lme4) [75]. Pairwise comparisons for soil trace gas production between treatments were conducted using Wilcoxon Rank Sum test and effect sizes were calculated using Mann-Whitney U Test. Differences in soil biogeochemical properties between treatment were tested using Kruskal-Wallis test and effect size was calculated using epsilon squared. Soil geochemical dissimilarity was calculated from scaled data using Euclidean distances (vegan $\mathrm{R}$ package). Then mean dissimilarity across GHG collars was used to construct linear mixed models to view changes in dissimilarity over time. Differences in microbial community structure across plot, site, and time were tested using a PERMANOVA test based on Bray Curtis and weighted-UniFrac dissimilarity for taxonomic and phylogenetic diversity, respectively. We used PERMDISP [76], a distance-based test for homogeneity of multivariate dispersion, to assess differences in beta diversity between treatments using the 'betadisper' function (vegan $\mathrm{R}$ package). Differences in relative abundance between groups and time points were calculated by multiple Student's $t$ tests; $p$-values were adjusted by conservative Bonferroni correction to compensate for increased Type 1 errors over multiple time points.

Structural equation modeling (SEM) was used to explore the direct and indirect relationships among environmental variables and GHG fluxes $\left(\mathrm{CO}_{2}\right.$ and $\left.\mathrm{CH}_{4}\right)$ at both sites. Based on correlation analyses among all variables (Fig. S3), we first considered a full model that included all reasonable pathways, then eliminated nonsignificant pathways until we obtained a final model with only significant pathways. We used a $\chi^{2}$ test and the root mean square error (RMSE) to evaluate the fit of our model. To correct for potential temporal autocorrelation, we used averaged microbial and environmental data for each trace-gas collar sampling location, averaged across time points within each plot. For the $\mathrm{CO}_{2}$ model, all sampling locations were pooled in a single SEM model $(n=84)$. However, for $\mathrm{CH}_{4}$, a consistent SG effect was found across the sites. Therefore, two models $(n=42)$ were created, one for the SG and one for FL plots to compare and identify differences in environmental factors that contribute to the $\mathrm{CH}_{4}$ fluxes between the two treatments. The SEM-related analysis was performed using the lavaan R package [77].

\section{Results}

\section{Changes in root biomass and soil chemistry}

We observed a large difference in the field-scale estimates of belowground root biomass (Fig. 1a) between the switchgrass
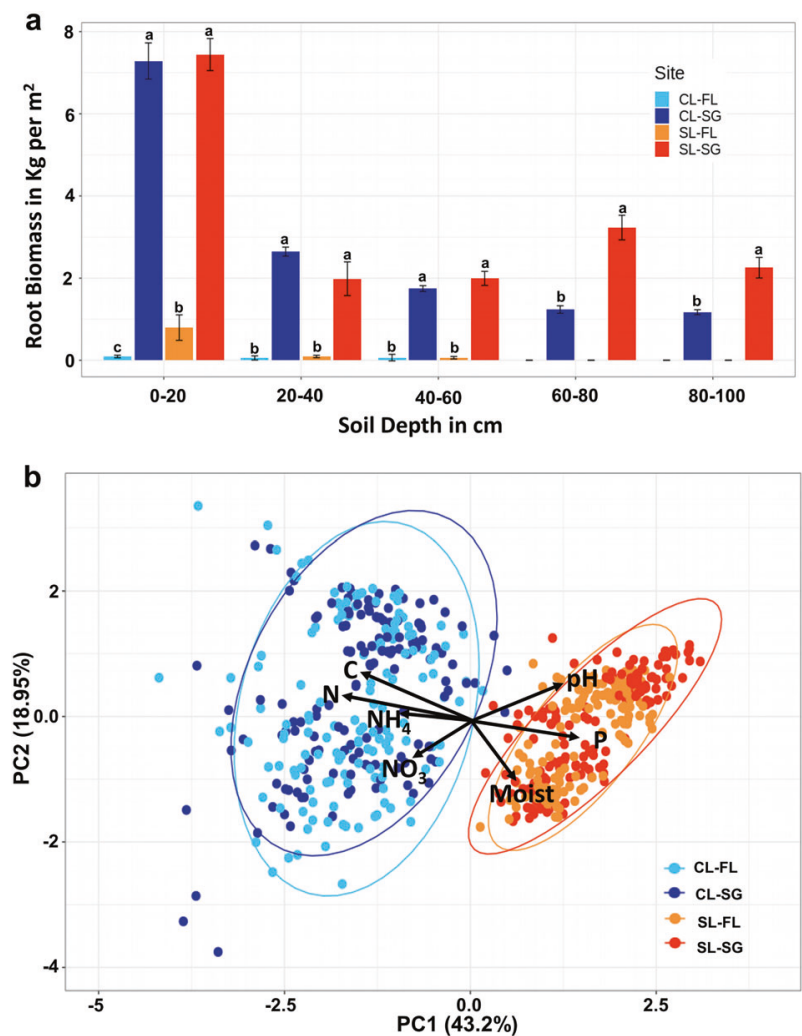

Fig. 1 Differences in root biomass estimates and soil chemical properties between the two studied sites. a Difference between fallow and switchgrass plots for estimated root biomass by depths $(n=4)$, letters indicate significant difference between groups by Student's $t$ test; b Principal component analysis of soil chemical properties by site and treatment (seasonal samples displayed, $n=588$ ). Blue colors represent the CL site while red/orange colors signify the SL site. Dark colors represent the SG samples. Variation contained in each PC axis are displayed next to each axis. 
a Clay Loam Soil
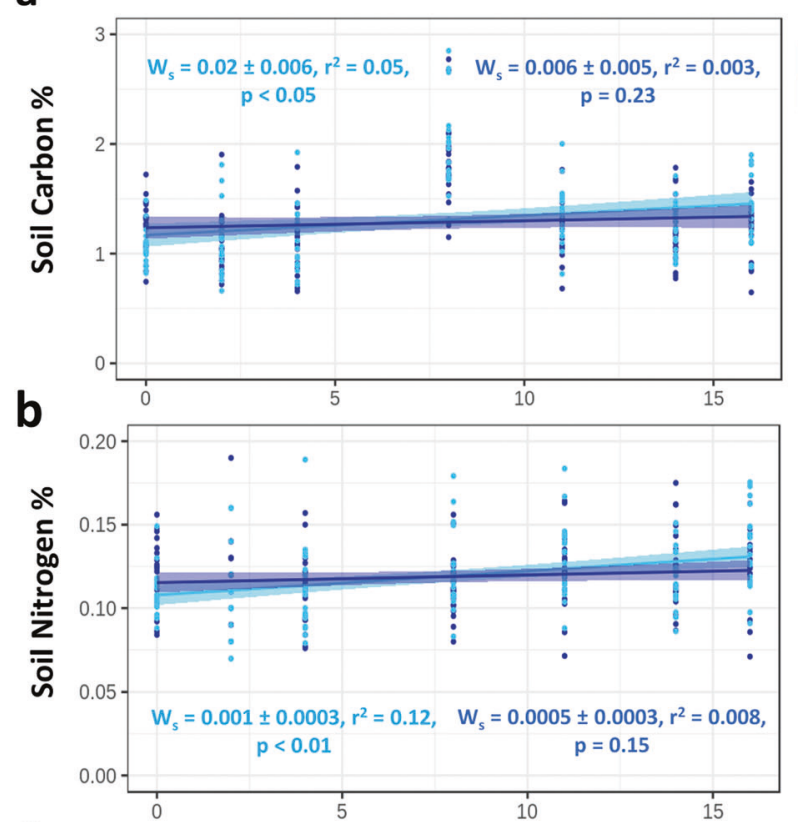

C

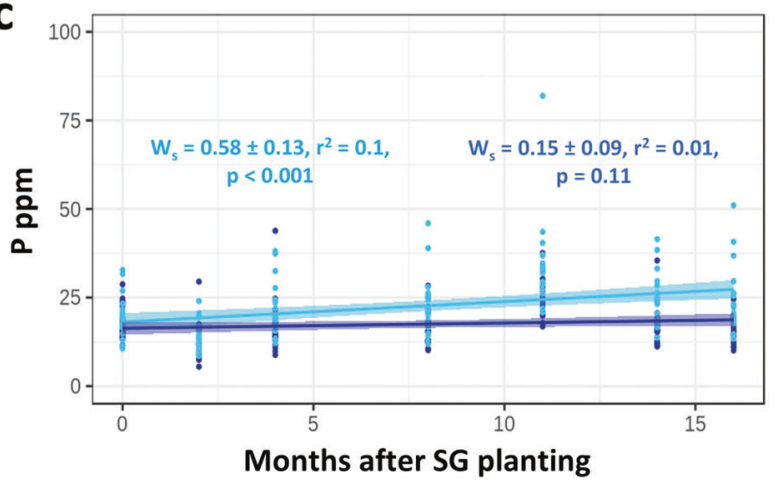

Fig. 2 Changes in soil chemistry through two seasons of switchgrass establishment. a Total soil carbon percentages. b Total soil nitrogen percentages. c Concentration of plant available phosphate content in parts per million. The best linear model describing the

and fallow plots (17.8 and 64 times higher for SL and CL, respectively). Root biomass was estimated for each soil layer in kilograms per meter squared. The estimated total root biomass of all soil layers in the top $1 \mathrm{~m}$ added together for the switchgrass plots was $16.9 \mathrm{~kg} / \mathrm{m}^{2}$ for the SL site and $14.1 \mathrm{~kg} / \mathrm{m}^{2}$ for the CL site, while the fallow plots had 0.95 $\mathrm{kg} / \mathrm{m}^{2}$ of roots in the SL and $0.22 \mathrm{~kg} / \mathrm{m}^{2}$ in the CL site. Generally, root biomass decreased along the soil depth at both sites. The SL switchgrass site had higher root biomass estimates at lower depths $(60-100 \mathrm{~cm}, p$ value $<0.05$ by Student's $t$ test) than the CL site, which contributed to a slightly higher total root biomass.

A principal component analysis (PCA) of the soil chemistry data (Soil $\mathrm{C}, \mathrm{N}, \mathrm{P}, \mathrm{NO}_{3}, \mathrm{NH}_{4}, \mathrm{pH}$, and soil moisture levels) revealed strong differences between the two sites (Fig. 1b). Heterogeneity of the geochemical parameters was higher at the CL site with an average
Sandy Loam Soil
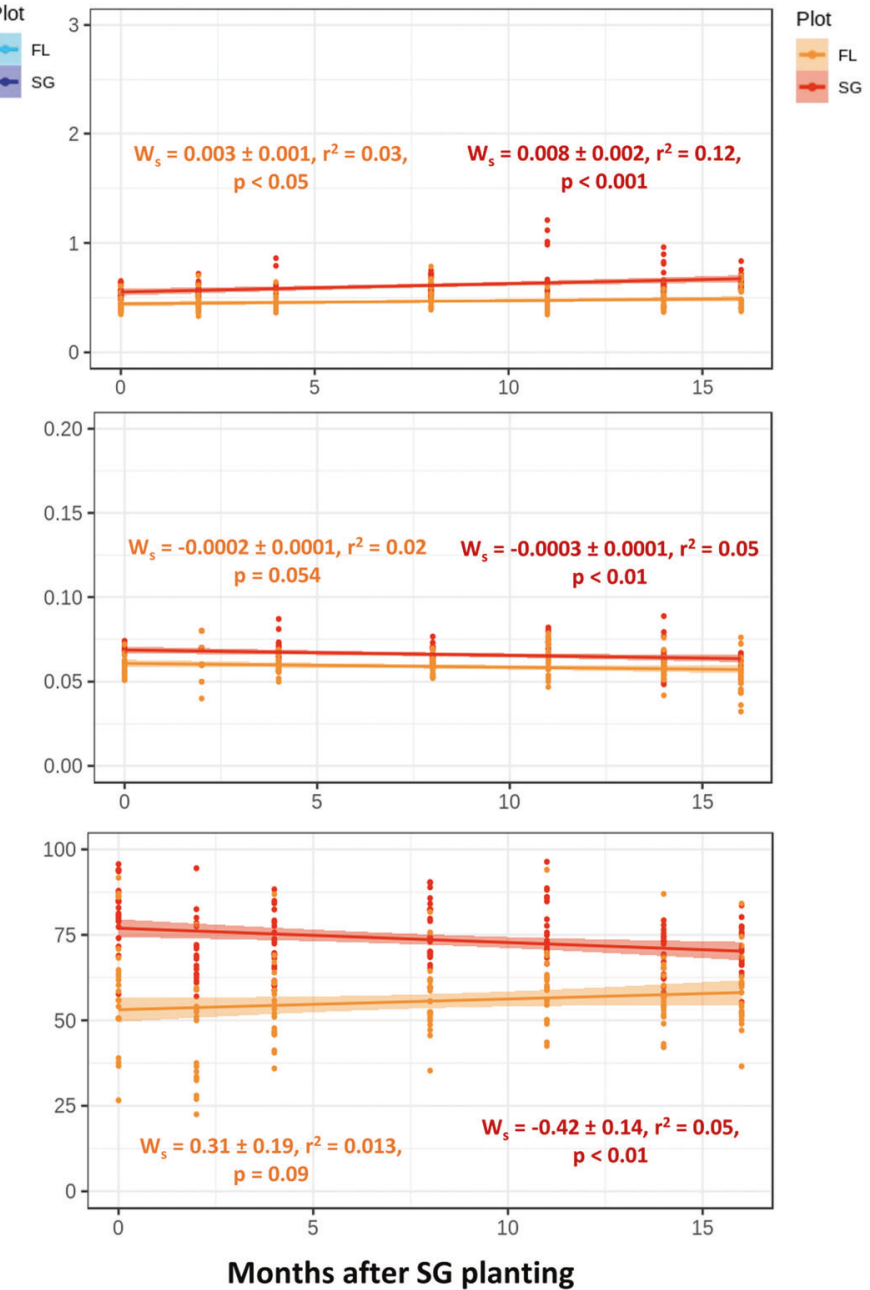

relationship is presented. $\mathrm{W}_{\mathrm{s}}$ : estimated model slope and associated error. $p$-values represent the significance of each model. Each time point is comprised of twenty-one replicates per plot $(n=588$, seasonal samples).

dissimilarity of $2.96 \pm 0.73$ compared with $2.52 \pm 0.24$ for the SL site, and illustrated by the greater dispersion of samples from the CL site in Fig. $1 \mathrm{~b}$.

The total soil surface $\mathrm{C}(0-20 \mathrm{~cm})$ at the SL site increased over the 17-month period in the switchgrass plot (Fig. 2a) $\left(r^{2}=0.12, p<0.001\right)$ and was significantly higher than in the fallow plot (Table $1, p<0.001$, large effect size $=0.4$ ). Switchgrass also had a homogenizing effect for soil C, probably due to the increase in belowground root biomass, and reduced the overall dissimilarity between samples compared to the fallow plots which had patchy plant cover. These increases in soil $\mathrm{C}$ occurred evenly across the plot area (Fig. S4a). In contrast, the total soil C content remained constant in the CL switchgrass plot (Fig. 2a).

Total surface soil $\mathrm{N}$ was significantly higher in the SL switchgrass plot compared to the fallow plot (Table $1, p<$ 0.0001 , medium effect size $=0.19$ ) and these $\mathrm{N}$ levels 


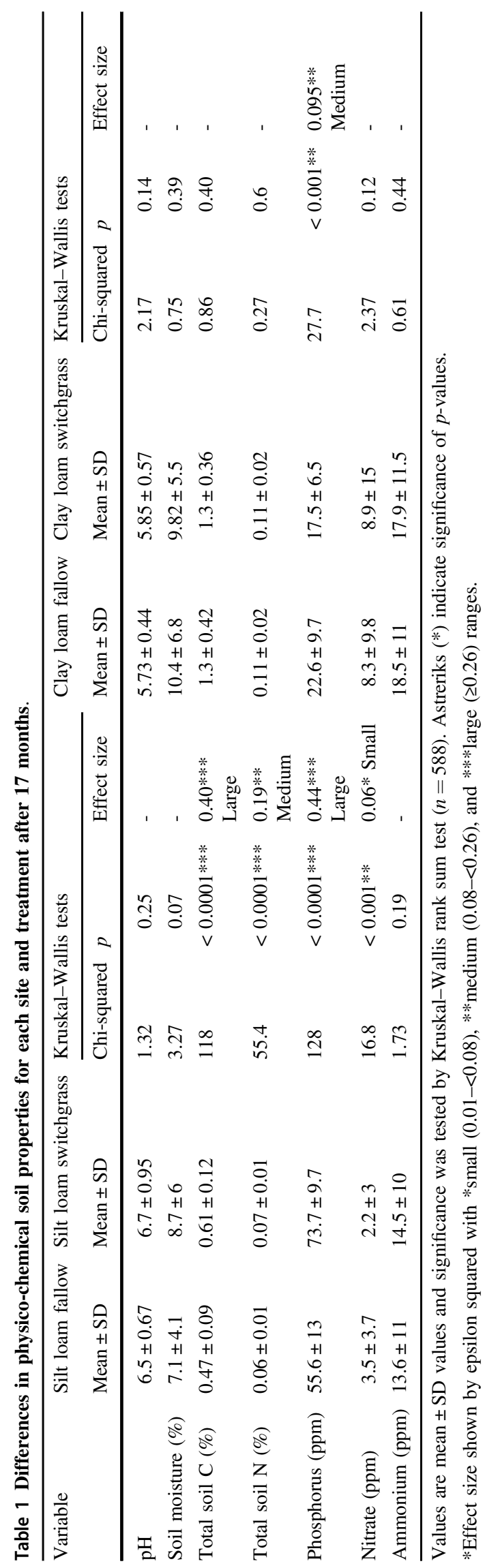

significantly decreased over time $\left(r^{2}=0.05, p<0.01\right)$ (Fig. 2b), coinciding with an increase in the soil $\mathrm{N}$ heterogeneity in the plot $\left(r^{2}=0.12, p<0.0001\right)$ (Fig. S4b). In contrast, we measured a significant increase in the total soil $\mathrm{N}$ in the CL fallow plot $\left(r^{2}=0.12, p<0.01\right)$ (Fig. 2b). Nitrate concentration were significantly reduced for the switchgrass treatment at the SL site (Table $1, p<0.001$, small effect size $=0.06$ ). All sites and plots showed a significant reduction in $\mathrm{NO}_{3}$ concentrations over time (Fig. S5a) along with increased homogeneity. No significant differences were observed in soil $\mathrm{NH}_{4}^{+}$concentrations during the length of our study at either site (Fig. S5b). Total plant available $\mathrm{P}$ levels decreased over time in the SL site $\left(r^{2}=0.05, p<0.01\right)$ (Fig. 2c) and became more homogeneous across the plot despite the SL switchgrass treatment having significantly higher total plant available $\mathrm{P}$ content compared to the fallow (Table $1, p<0.0001$, large effect size $=0.44)$. In the CL site, plant available $P$ also decreased in the switchgrass plot compared to the fallow (Table $1, p<$ 0.001, medium effect size $=0.095$, and Fig. $2 \mathrm{c}$ ).

\section{Greenhouse gas (GHG) fluxes at the soil-atmosphere interface}

$\mathrm{CO}_{2}$ flux exhibited a similar seasonal trend at both sites with the apex of emissions occurring during summer months and the minimum in late Fall/early Winter months (Fig. 3). At the SL site, switchgrass treatment led to significantly higher total $\mathrm{CO}_{2}$ flux for $29 \%$ of the months after switchgrass planting (Wilcoxon $p<0.001$, Fig. 3a) while the fallow was significantly higher for only $24 \%$ of the total months measured. The average $\mathrm{CO}_{2}$ flux over the 17 months did not differ in the SL site between switchgrass $\left(6.76 \pm 5.23\right.$ millimoles $\left.\mathrm{m}^{2} \mathrm{~h}^{-1}\right)$ and the fallow plots $\left(6.87 \pm 5.87\right.$ millimoles $\left.\mathrm{m}^{2} \mathrm{~h}^{-1}\right)$. At the $\mathrm{CL}$ site, there was a significant difference between plot treatments in the average $\mathrm{CO}_{2}$ flux over the 17-month period $(p<0.001)$ with the switchgrass plot at $9.98 \pm 6.04$ millimoles $\mathrm{m}^{2} \mathrm{~h}^{-1}$ and the fallow at $9.22 \pm 6.62$ millimoles $\mathrm{m}^{2} \mathrm{~h}^{-1}$, although the effect size was small (0.13). When comparing the two sites, the CL site had significantly higher total soil $\mathrm{CO}_{2}$ fluxes for both switchgrass and fallow plots than those measured at SL (Wilcoxon $p<0.001$ ).

$\mathrm{CH}_{4}$ fluxes (Fig. 3b, Table S4) differed significantly between switchgrass and fallow (Wilcoxon $p<0.001$, small effect size $=0.15$ ), with a tendency toward higher $\mathrm{CH}_{4}$ emissions or lower $\mathrm{CH}_{4}$ consumption levels in the switchgrass plots for $41 \%$ of the months after switchgrass was planted (41 and $52 \%$ for $\mathrm{CL}$ and SL, respectively). $\mathrm{CH}_{4}$ flux in the CL fallow was higher only at one time point $\left(14^{\text {th }}\right.$ month after switchgrass establishment). Overall, the 17month average $\mathrm{CH}_{4}$ consumption rate was $-0.44 \pm 1.07$ micromoles $\mathrm{m}^{2} \mathrm{~h}^{-1}$ for switchgrass treatments $(-0.46 \pm$ 1.08 and $-0.41 \pm 1.06$ micromoles $\mathrm{m}^{2} \mathrm{~h}^{-1}$ for $\mathrm{CL}$ and SL, 

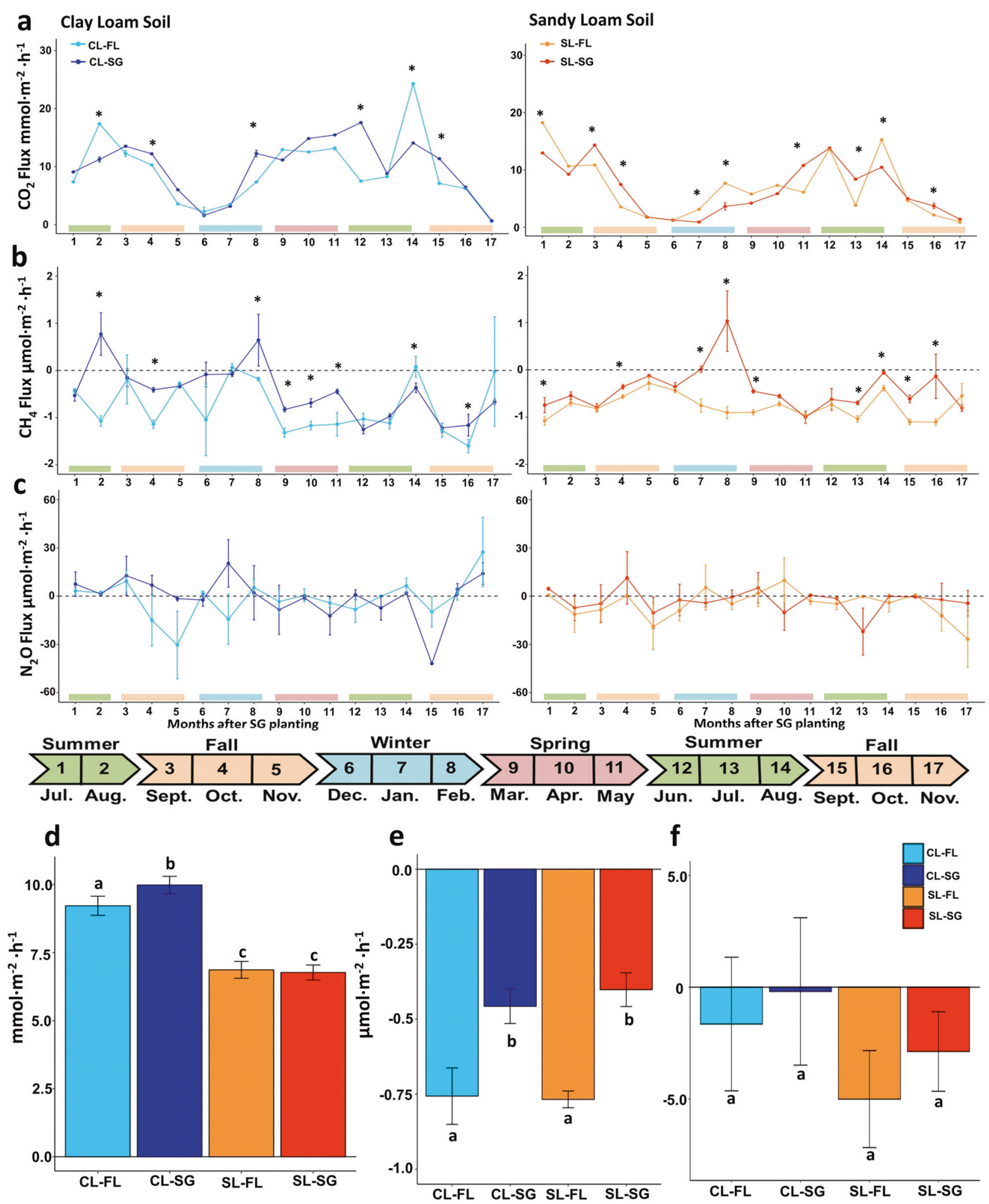

Fig. 3 Greenhouse gas (GHG) fluxes during grassland conversion to switchgrass. a, b, c GHG fluxes at each site over 17 months (mean and standard error estimated using 21 replicates for each time points, $n=1428$ ) for: a carbon dioxide flux; $\mathbf{b}$ methane flux; $\mathbf{c}$ nitrous oxide.

d Average GHG fluxes over 17 months for d carbon dioxide; e methane flux; $\mathbf{f}$ nitrous oxide flux. Different letters and asterisk indicate significant difference between groups by Wilcoxon sign test with $p$-value $<0.01$. 
a

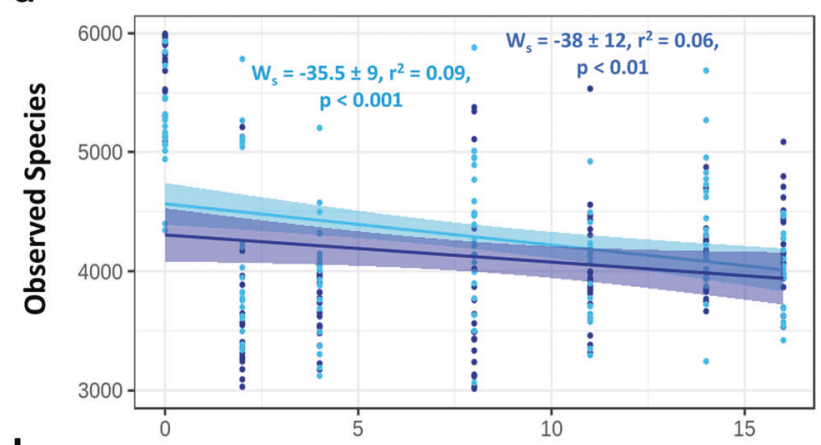

b

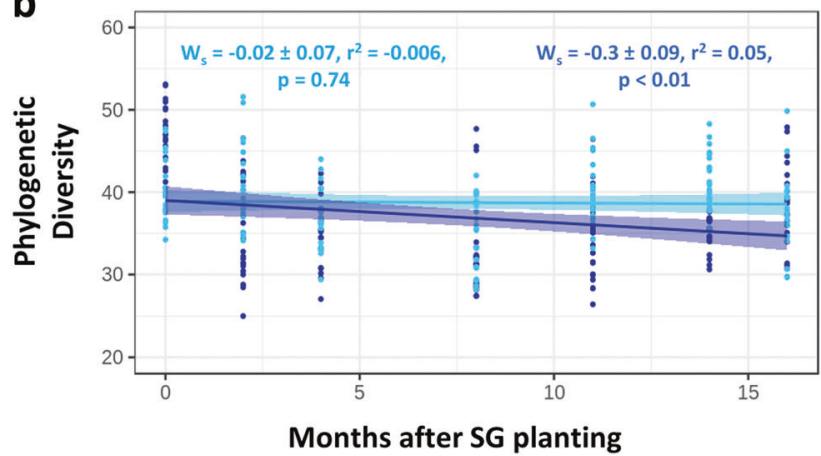

C

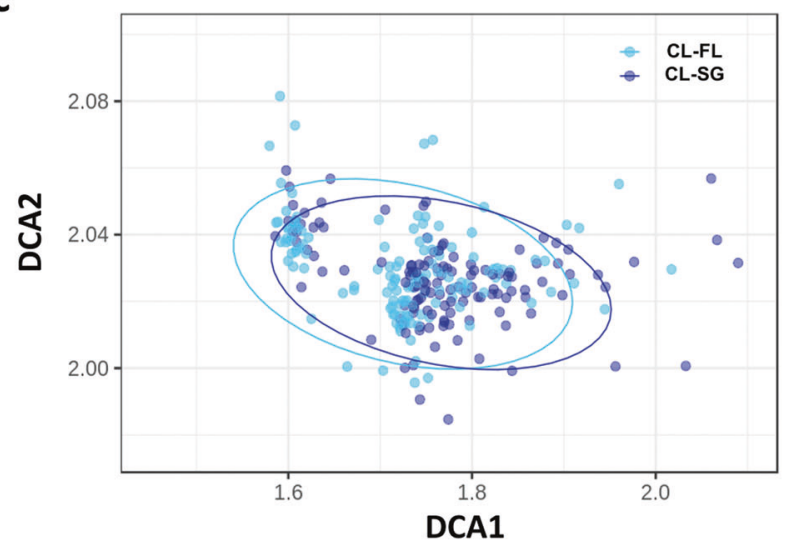

Fig. 4 Changes in microbial diversity and structure in response to switchgrass planting. a Number of observed species through time. b Phylogenetic diversity. c Detrended correspondence analysis of the $16 \mathrm{~S}$ community separated by site for all time points and plots $(n=$

respectively) and $-0.77 \pm 1.15$ in the fallow $(-0.76 \pm 1.78$ and $-0.77 \pm 0.53$ micromoles $\mathrm{m}^{2} \mathrm{~h}^{-1}$ for CL and SL, respectively) (Fig. 3e, Table S4). Taken together, we observed a significant effect of switchgrass cultivation, with reduced $\mathrm{CH}_{4}$ consumption rates at both sites $(p<0.05$, a small effect size $=0.14$ ).

We did not measure significant differences for $\mathrm{N}_{2} \mathrm{O}$ fluxes between the switchgrass $\left(-0.26 \pm 2.55\right.$ micromoles $\mathrm{m}^{2} \mathrm{~h}^{-1}$ at $\mathrm{CL}$ and $-2.88 \pm 2.09$ micromoles $\mathrm{m}^{2} \mathrm{~h}^{-1}$ at SL) and fallow plots $\left(-1.65 \pm 2.5\right.$ micromoles $\mathrm{m}^{-2} \mathrm{~h}^{-1}$ at $\mathrm{CL}$ and $-5.01 \pm$ 2.16 micromoles $\mathrm{m}^{-2} \mathrm{~h}^{-1}$ at SL) at either site over the 17 months of observations (Fig. 3f).
Sandy Loam Soil
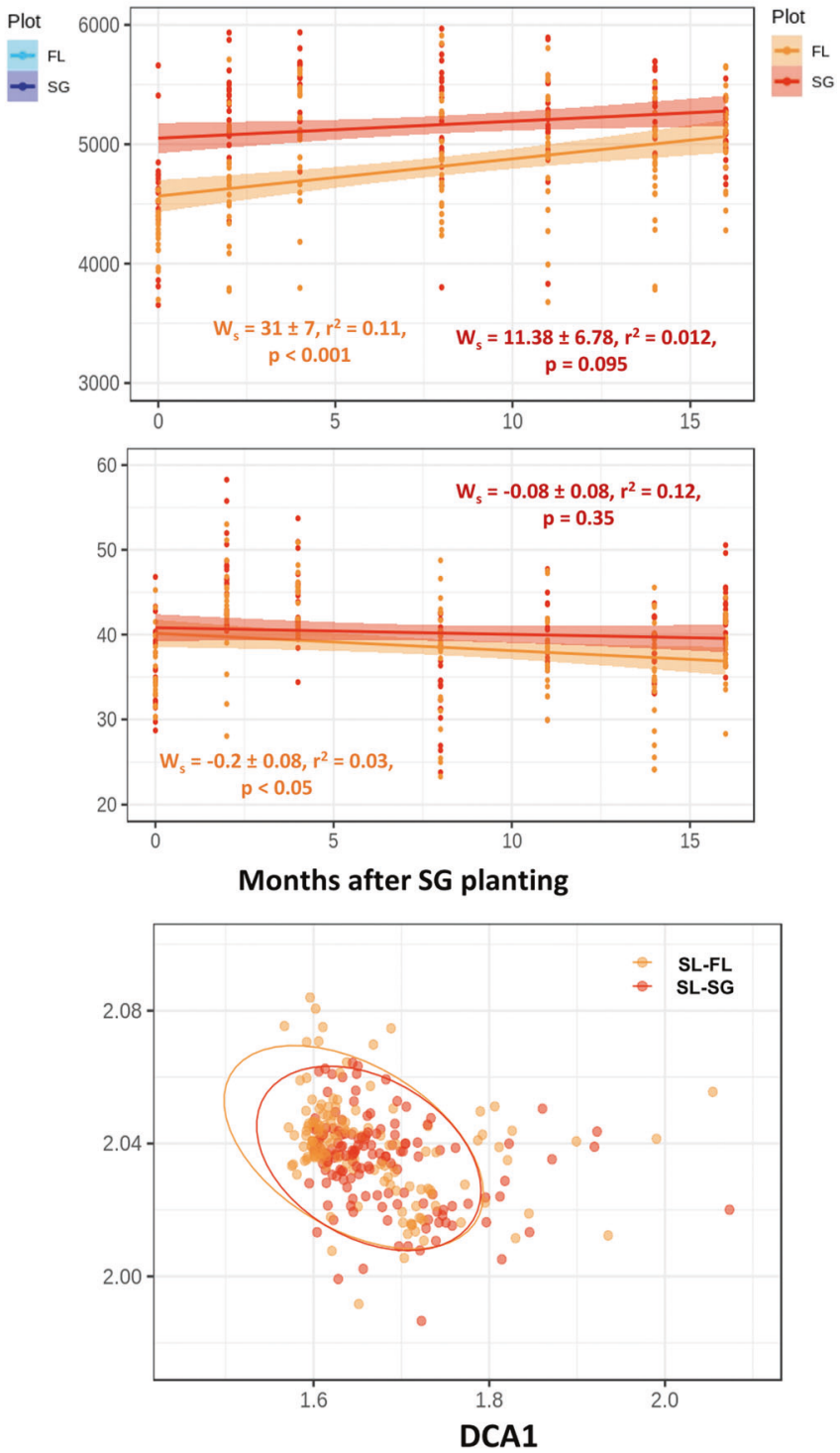

1428). Significant differences were found between sites, plant cover types, and through time (PERMANOVA, $p<0.01$ ). Dark colors represent the switchgrass samples.

\section{Microbial community dynamics}

Microbial alpha diversity, calculated as OTU richness, showed a site-specific response to switchgrass cultivation. In the SL site, OTU richness was significantly higher in the switchgrass plot (Table $\mathrm{S} 4, p<0.0001$, medium effect size $=0.38$ ). OTU richness did not change over time in the SL switchgrass plot (Fig. 4a) but increased in the fallow plot $(p<0.001)$, despite a decrease in phylogenetic diversity (PD) $(p<0.05$, Fig. $4 \mathrm{~b})$. At the CL site, microbial species richness decreased significantly over time in both switchgrass $(p<0.01)$ and fallow plots $(p<0.001)$. For PD, this decay was observed only in the 
switchgrass plot $(p<0.01)$. Chaol and Shannon indices showed similar trends per site over time (Fig. S6). Switchgrass cultivation significantly (PERMDISP, $p<0.05$ ) decreased the beta diversity at the $\mathrm{CL}(\mathrm{FL}=0.2323$ and $\mathrm{SG}=0.2179)$ and $\mathrm{SL}(\mathrm{FL}=0.2349$ and $\mathrm{SG}=0.2273)$ sites when compared to the paired fallow plots, with decreases in the average distance to the median for the homogeneity of multivariate dispersion.

We observed significant differences in the bacterial community structure (beta diversity) between sites, plant cover type, and over time (Fig. 4c, PERMANOVA, $p<$ 0.01 , Table S5). Relative abundance of major phyla showed large changes from the initial planting and two months after the experiment began (Fig. 5). At all sites, at least five abundant phyla exhibited changes in relative abundance. The relative abundance of Firmicutes (0.6-0.14\%) changed over the course of the experiment in both fallow plots. The structure of microbial communities from the switchgrass plots appeared less variable than in the corresponding fallow plots. In the CL site, the strongest differences in dominant phyla relative abundance between plots (switchgrass vs fallow) were observed at eight and fourteen months after switchgrass planting (February 2017 and August 2017, Table S6). After eight months, seven phyla (Actinobacteria, Bacteroidetes, Chloroflexi, Deinococcus-Thermus, Firmicutes, Planctomycetes, and Verrucomicrobia) exhibited different abundance between treatment, while only four phyla (Actinobacteria, Chloroflexi, Cyanobacteria, and Deinococcus-Thermus) were different after 14 months. For the SL site, the largest shifts in community composition occurred in the last two time points, i.e., 14 and 16 months after switchgrass establishment. After 14 months, three phyla were significantly different between treatment (Acidobacteria, Bacteroidetes, and Deinococcus-Thermus) and after 16 months four groups were significantly different (Acidobacteria, Bacteroidetes, Cyanobacteria, and Verrucomicrobia).

We used canonical correspondence analysis (CCA) to link environmental variables to the microbial community (Fig. 6). A clear separation between microbial communities from the two sites was observed. Microbial communities from the SL site were correlated with plant available $\mathrm{P}$ and soil $\mathrm{pH}$, while $\mathrm{CL}$ communities were associated with total soil $\mathrm{N}, \mathrm{NH}_{4}$, and $\mathrm{NO}_{3}$. In addition, fallow communities from CL were far more dispersed, with switchgrass soil communities at this site clustered by $\mathrm{N}$ source or along a soil moisture gradient.

\section{Structural equation model links microbial features to soil properties and trace gas fluxes}

Structural equation modeling (SEM) was used for an indepth analysis of the direct and indirect effects of environmental drivers on $\mathrm{CO}_{2}$ and $\mathrm{CH}_{4}$ fluxes. For $\mathrm{CO}_{2}$ fluxes
(Fig. 7a) the model confirmed the importance of the site effect on soil $\mathrm{C}$ and microbial communities, with strong direct effects (based on standardized coefficient) being directed from the site and toward total $\mathrm{C}(\beta=-0.48, p<$ $0.05)$ and microbial alpha diversity $(\beta=0.89, p<0.05)$. Plant available $\mathrm{P}$ strongly influenced the levels of $\mathrm{C}(\beta=$ $0.59, p<0.01)$ and microbial biomass in the system $(\beta=$ $-0.28, p<0.05)$. Important variables influencing $\mathrm{CO}_{2}$ fluxes included soil temperature $(\beta=0.33, p<0.05)$, microbial biomass $(\beta=0.33, p<0.05)$ and plant cover $(\beta=$ $0.16, p<0.05)$. Microbial biomass appeared mostly dependent on $\mathrm{N}$ content $(\beta=0.68, p<0.001)$ and to a lower extent on $\mathrm{P}$ content and the type of plant cover.

In the SEM model for $\mathrm{CH}_{4}$ in switchgrass plots (Fig. 7b), the site effect was pronounced and mostly directed toward $\mathrm{P}$ levels $(\beta=0.95, p<0.001)$ and soil $\mathrm{C}$ levels $(\beta=-0.91$, $p<0.001)$. Soil temperature did not have an influence on $\mathrm{CH}_{4}$ fluxes directly, it was important in this model via its direct effects on soil moisture $(\beta=0.21, p<0.01), \mathrm{P}(\beta=$ $0.1, p<0.01)$, and microbial biomass $(\beta=0.11, p<0.05)$. Microbial biomass was influenced by soil $\mathrm{C}(\beta=0.6, p<$ $0.001)$, plant available $\mathrm{P}(\beta=-0.53, p<0.001)$, nitrate level $(\beta=-0.17, p<0.01)$, and soil temperature $(\beta=0.11$, $p<0.05)$. Overall, we found that $\mathrm{CH}_{4}$ fluxes in the SG plots were directly depended on microbial biomass $(\beta=-0.73$, $p<0.05)$ suggesting a biological effect to the $\mathrm{CH}_{4}$ fluxes. In contrast, the SEM model for $\mathrm{CH}_{4}$ fluxes at the $\mathrm{FL}$ plots (Fig. 7c) suggested more environmental regulation, as soil moisture $(\beta=0.97, p<0.001)$, plant available $\mathrm{P}(\beta=0.86$, $p<0.01)$, soil temperature $(\beta=0.48, p<0.001)$, and soil $\mathrm{C}$ $(\beta=-0.48, p<0.05)$ directly influenced $\mathrm{CH}_{4}$ fluxes.

\section{Discussion}

In this study, we examined the differences of soil chemistry, microbial community structure, and GHG fluxes in contrasting soil types with or without switchgrass. As hypothesized, increases in $\mathrm{CO}_{2}$ production, and a reduction in alpha and beta microbial community diversity were observed in the CL switchgrass plot. In contrast, at the SL site, we observed an increase in microbial alpha diversity, while beta diversity was reduced; there were no differences in $\mathrm{CO}_{2}$ production at this site. However, an increase in topsoil $\mathrm{C}$ levels was observed between plots with and without switchgrass for the SL site. Our most striking result is the observation of a systematic and significant reduction of $\mathrm{CH}_{4}$ consumption rates, which altered the soil $\mathrm{CH}_{4}$ sink capacity in the switchgrass plots. Although the $\mathrm{CH}_{4}$ emission rates in this relatively mesic landscape were far lower than those reported for systems with anaerobic, waterlogged conditions like peatlands [78] and wetlands [79], $\mathrm{CH}_{4}$ emission effects may not be negligible during marginal 

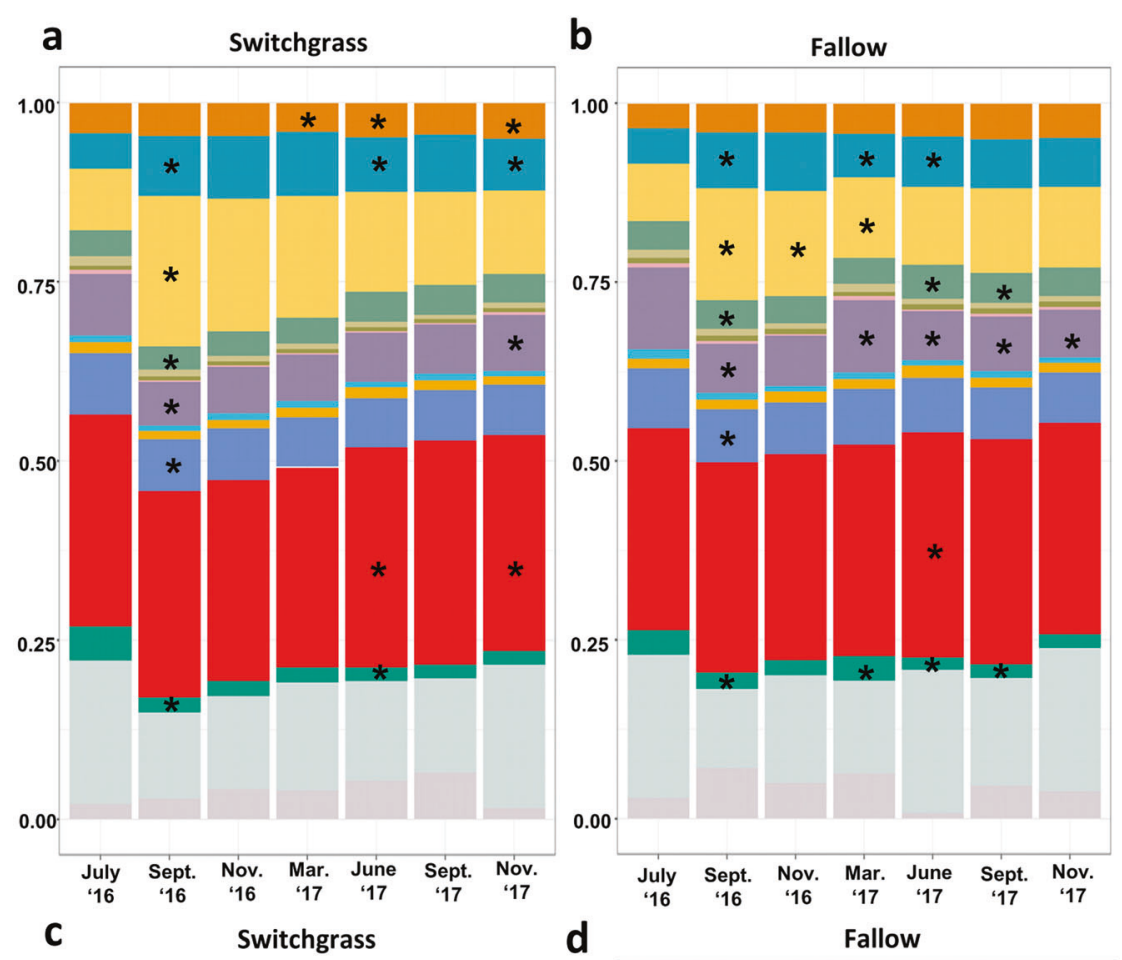

Clay Loam Soil
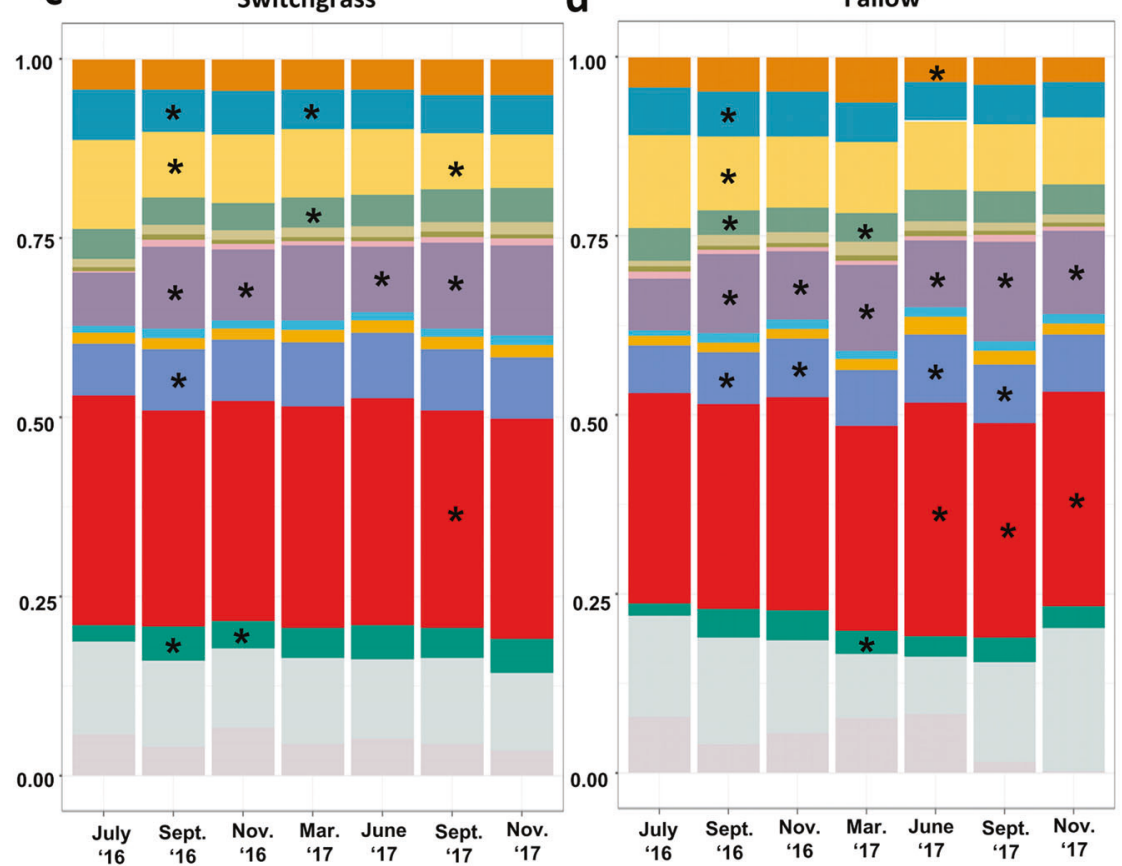

Acidobacteria
Actinobacteria
Bacteroidetes
Chlamydiae
Chloroflexi
Cyanobacteria/Chloroplast
Deinococcus-Thermus
Firmicutes
Gemmatimonadetes
Parcubacteria
Planctomycetes
Proteobacteria
Verrucomicrobia
Unclassified
Others

Sandy Loam Soil

Fig. 5 Changes of relative abundance for major phyla. Taxonomic identity was determined with the RDP classifier at $80 \%$ sequence match criteria. OTU table was trimmed by abundant OTUs $(>0.001 \%)$. Difference between time points within each plot for: a Clay-loam switchgrass (CL-SG) plot; b Clay-loam fallow (CL-FL) plot; c Sandyloam switchgrass (SL-SG) plot; d Sandy-loam fallow (SL-FL) plot. Significant differences between the previous time point for each group denoted by asterisk (*) symbols within each phyla bar. land transitions to switchgrass row-cropping [40] due to the severity of its global warming potential (28 to 34 times higher than $\mathrm{CO}_{2}$ ). However, comprehensive GHG budgets along with spatially explicit modeling of soil and plant $\mathrm{C}$ stocks, should be considered to fully evaluate the effect of large-scale conversion at these prairie sites.

\section{Soil type dictates the effects that switchgrass has on geochemistry}

Our study revealed significant site-level differences in soil $\mathrm{C}$ accrual, total soil $\mathrm{N}$ levels, and depletion of soil $\mathrm{P}$ content after switchgrass establishment. The CL site, with initially 
Fig. 6 Relationships between environmental factors and microbial communities structure. Canonical

correspondence analysis (CCA) linking microbial communities structure with environmental variables $(n=1428)$. Samples are shown by plot and site type with significant environmental variables shown in black arrows.

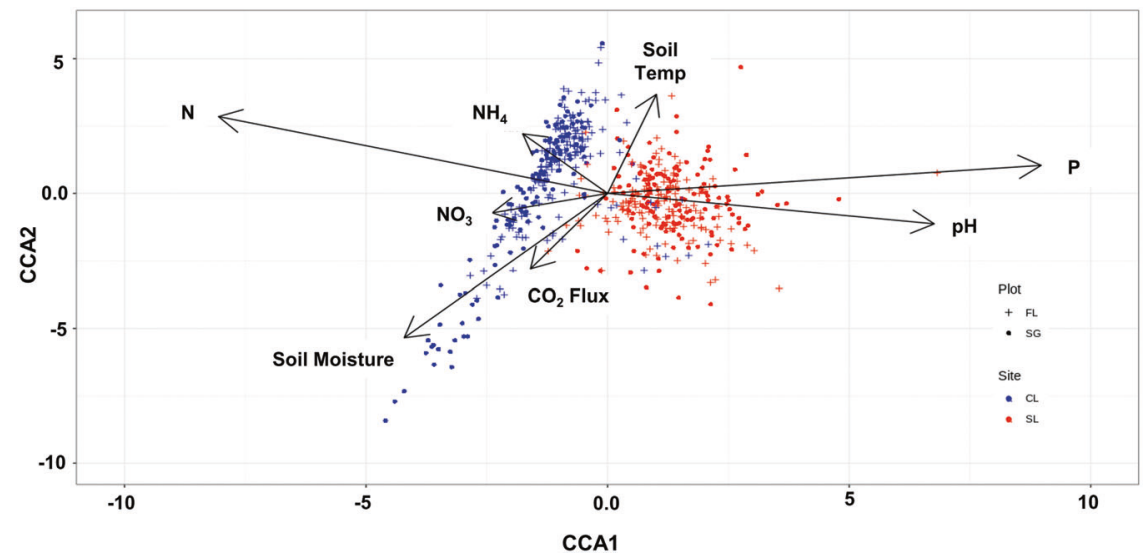

a

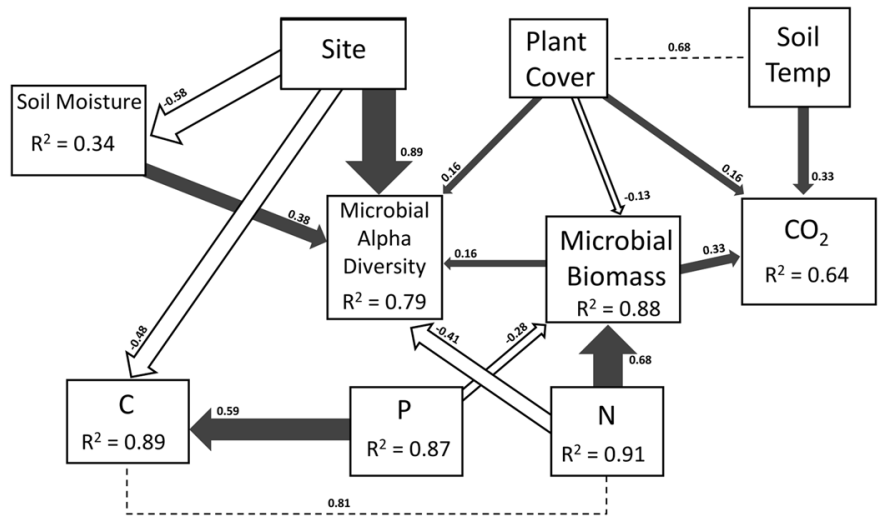

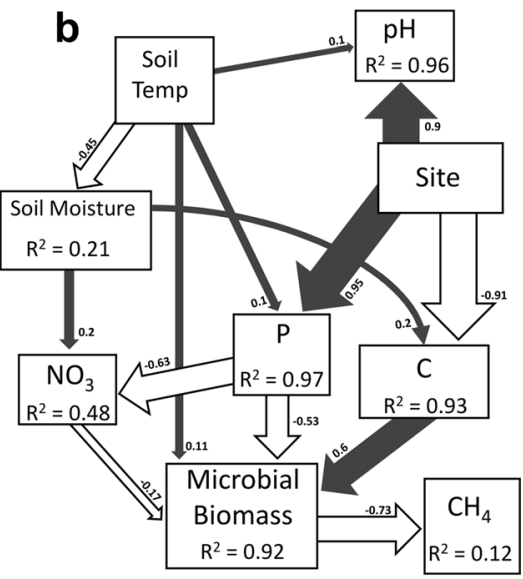

Fig. 7 Structural equation modeling showing the relationships among environmental variables and GHG fluxes. a Model for total carbon dioxide flux generated from the seasonal data $\left(\chi^{2}=13.355\right.$, d.f. $=9, P=0.147, n=84$ ). b Model for methane flux generated from seasonal data of switchgrass plots only $\left(\chi^{2}=18.02\right.$, d.f. $=17, P=$ $0.388, n=42)$. c Model for methane flux generated from seasonal data of fallow plots only $\left(\chi^{2}=7.131\right.$, d.f. $\left.=6, P=0.309, n=42\right)$. Dark gray and white arrows represent significant $(p<0.05)$ positive and negative pathways, respectively. Numbers near the pathway arrows indicate the standard path coefficients $(\beta)$. Width of the arrows are

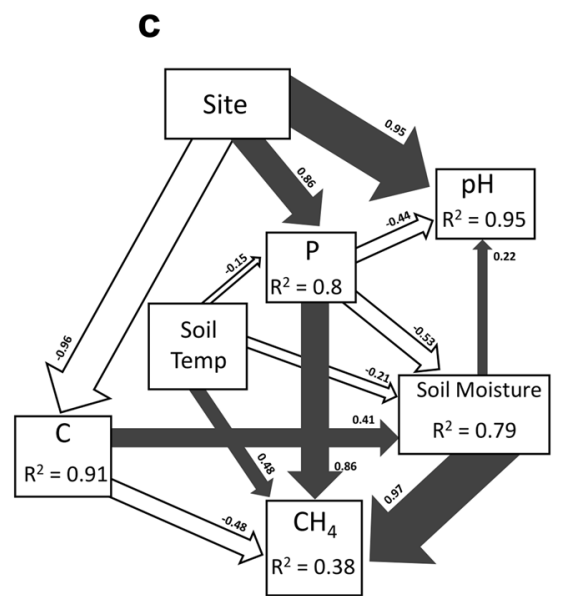

proportional to the strength of the relationship. Dashed lines represent residual correlations accounted for in the model. Plant Cover $=$ Switchgrass (positive) or mixed annual grassland plant cover (negative) at the plot; Site $=\mathrm{SL}$ (positive) or CL (negative) soil site; $\mathrm{CO}_{2}=$ total soil carbon dioxide flux; Soil Temp $=$ soil temperature at a depth of $10 \mathrm{~cm}$ for bare soil in degrees Celsius; Soil Moisture $=$ gravimetric per cent soil moisture; $\mathrm{P}=$ plant available phosphorus content; Microbial Alpha Diversity = number of observed bacterial species per sample; $\mathrm{NO}_{3}=$ nitrate concentrations; $\mathrm{CH}_{4}=$ methane flux; and $\mathrm{pH}=$ soil $\mathrm{pH}$. 
higher relative nutrient content, showed little change over time (17 months) for any of the soil geochemical parameters. Reported [12] changes in soil geochemistry by switchgrass cultivation in CL soils were only detected after longer periods of time (over a decade). It is likely that prolonged sampling at our CL site would provide improved assessments of switchgrass-induced soil $\mathrm{C}$ changes. We also noted that nitrate content (Fig. S5a) significantly declined with time, over switchgrass establishment, which may suggest assimilation by the plants, microbes, or an increased activity of denitrifying bacteria.

Surface soil C content significantly increased at the SL site (27\% higher total $\mathrm{C}$ after two growing seasons) over the course of switchgrass establishment. This is consistent with other estimates showing switchgrass systems can increase soil $\mathrm{C}$ stocks in a relatively short amount of time [13, 80]. However, we observed significant depletion in soil $\mathrm{N}$ and $\mathrm{P}$ contents at the SL site with switchgrass over time, though we note that these values were higher than those in the fallow from the beginning of our experiment. One explanation for this observation is that $\mathrm{N}$ and $\mathrm{P}$ have been taken up into the switchgrass tissue, which could explain the higher belowground root biomass observed in the SL site at lower soil depths. Indeed, the higher plant available $\mathrm{P}$ conditions at this site could allow switchgrass to extend deeper into the subsurface soils for water or micronutrient availability and thus support a greater investment of belowground root biomass.

Seasonal sampling of $\mathrm{NH}_{4}-\mathrm{N}$ was not sufficient in explaining large seasonal variations observed over the time course of our experiment. For example, a spike in soil $\mathrm{NH}_{4}$ levels (Fig. S5b) was detected during October of 2016 and June of 2017, which could be the signature of episodic $\mathrm{N}$ fixation events occurring in switchgrass during/before flowering as reported previously [81]. However, our temporal resolution for this geochemical parameter was not detailed enough to adequately explain these anomalies.

\section{Microbial community shifts under switchgrass establishment}

Microbial community diversity and composition at each site had differential responses to switchgrass establishment. Broadly, alpha diversity measures in the CL switchgrass plot decreased over time and revealed a higher amount of clustering and similarity in the overall community structure compared with the fallow. Analogous to secondary plant successional dynamics, the microbial community at the CL site may be more influenced by the change from short rooted annuals to the monoculture of deep-rooted perennial switchgrass, causing a loss in microbial diversity [82], with a lower number of taxa and more homogeneous community composition. This follows our expectations (hypothesis iii) that switchgrass cultivation would lower microbial alpha and beta diversity. However, for SL, the Shannon index significantly increased over time under switchgrass cultivation and the community composition was altered. This result may be indicative of switchgrass-induced improvements in soil quality (increased soil C concentrations), which led to changes in functionality [83].

Microbial community structure was altered by switchgrass establishment (Table S5) and through time at each of the sites relative to the fallow soil communities. These changes in community structure may reflect different survival strategies that switchgrass may employ in the recruitment of specific taxa to its rhizosphere based on differences between the geochemistry of the two sites. Several previous studies provide evidence that switchgrass can recruit a beneficial microbiome, particularly mycorrhizal fungi, associative $\mathrm{N}$-fixing bacteria, and fungal endophytes [28]. Future investigations into rhizosphere microbiome succession [43-45] during establishment may provide insights into direct plant-microbe interactions that facilitate switchgrass establishment in these nutrientpoor soils.

\section{Factors controlling soil GHG flux}

Contrary to our hypothesis, $\mathrm{CO}_{2}$ production was significantly enhanced by switchgrass establishment only at the CL site. Based on previous studies [24, 25], we expected higher root respiration and the potential for deep $\mathrm{C}$ mineralization to enhance $\mathrm{CO}_{2}$ production at both sites after switchgrass establishment. However, the $\mathrm{CL}$ site had an overall higher $\mathrm{CO}_{2}$ emission rate during our field monitoring. This response may be mediated by the relatively higher preexisting C content found at this CL site [84], since root biomass levels were estimated to be similar at each site. Our SEM model revealed direct linkages between microbial biomass and $\mathrm{CO}_{2}$ production, suggesting that the amount of microbes in the soil play an important role in regulating $\mathrm{CO}_{2}$ flux and has long been linked to land usage and environmental variables that influence $\mathrm{CO}_{2}$ flux [85]. Overall, our study suggests differential $\mathrm{CO}_{2}$ production responses that depend on soil type when under the same land usage (i.e., switchgrass cultivation). Based on our results and those measured for the entire active soil horizon in nearby sites [13], SL marginal sites may provide more sustainable benefits in terms of increased $\mathrm{C}$ accrual during switchgrass establishment, as well as reductions in surface $\mathrm{CO}_{2}$ fluxes.

With our methane flux monitoring, we showed a significant reduction in $\mathrm{CH}_{4}$ consumptions at both sites with switchgrass cultivation. Although $\mathrm{CH}_{4}$ emission rates were low and measured at only a few time points within the switchgrass plots, consistently lower $\mathrm{CH}_{4}$ consumption 
rates were observed in the switchgrass plots relative to the fallow plots throughout the experiment. Total $\mathrm{CH}_{4}$ consumption rates for switchgrass plots were 47 and 39\% lower than in the corresponding fallows for CL and SL, respectively. During the period of 2008-2017, global emissions from both agriculture and waste sources were estimated to be $206 \mathrm{Tg} \mathrm{CH}_{4} \mathrm{y}^{-1}$, which represents $56 \%$ of the total anthropogenic emissions [86]. Recent estimates for 2018 and 2019 have shown an increase in atmospheric methane by 8.5 and $10.7 \mathrm{ppb}$ [87], respectively, prompting the need for future mitigation, since $\mathrm{CH}_{4}$ has 28 to 34 times the global warming potential (GWP) over a 100-year time horizon than $\mathrm{CO}_{2}$ [88]. Based on our results, $\mathrm{CH}_{4}$ flux profiles of each site may be altered by an estimated $0.48 \mathrm{~kg} \mathrm{ha}^{-1} \mathrm{yr}^{-1}$ when cultivated with switchgrass. Methane flux from our SEM models was also found to be correlated with microbial biomass, but only in the SG plots, suggesting a potential biological effect of switchgrass on the microbial community, which may have promoted the growth of key community members that can alter methane emissions (i.e., methanogens or methanotrophs). However, our analyses of community composition could not support further associations between $\mathrm{CH}_{4}$ flux and microbial community members. In contrast to $\mathrm{CO}_{2}$ and $\mathrm{CH}_{4}$ fluxes, we did not observe any significant effect between soil type and plant cover type (switchgrass vs fallow) on $\mathrm{N}_{2} \mathrm{O}$ fluxes in these marginal, sustainably managed (no fertilizer) soils.

\section{Conclusion}

Overall, total soil C levels increased by $27 \%$ following switchgrass planting and 17 months of monitoring in our SL site, but remained unchanged in our CL site. Total $\mathrm{CO}_{2}$ production was significantly affected under switchgrass at the $\mathrm{CL}$ site but not at the SL site. The annual $\mathrm{CH}_{4}$ consumption was reduced by 39 to $47 \%$ under switchgrass, implying that methane fluxes should be accounted for in $\mathrm{C}$ budgets to reach a sustainable cultivation of switchgrass. Switchgrass establishment had a significant influence on the microbial community composition over time and homogenized soil microbiota profiles at both sites. Considerations of soil type and nutrient conditions should be factors in the selection of future sites for sustainable large-scale bioenergy cultivation in order to meet objectives for terrestrial $\mathrm{C}$ sequestration and improved soil fertility.

Acknowledgements We would like to thank the Oklahoma Mesonet environmental monitoring network, and particularly Bradley Ilston, for the use of their weather monitoring stations. We deeply appreciate all the help from the auxiliary staff and field hands from the Nobel Research Institute, who aided us in collecting data and maintaining the field sites for this project. A. Escalas and C. Bates give special thanks to Randy Freeman, who helped make sample collection and processing possible. We would also like to thank the following personnel for their contributions to field sampling and molecular work: Zhigang Wang, Yuguang Zhang, Ning Hu, Yan He, Zhongfang Li, Qian Li, Jinyu Hou, Xiubin Ke, Juan Ling, Zheng Gao, and Daniel Curtis. C. Bates would also like to thank Tanya Ball for support during this project. This research is supported by the U.S. Department of Energy Office of Science, Office of Biological and Environmental Research Genomic Science program under the award number DE-SC0014079 to the UC Berkeley, Nobel Research Institute, University of Oklahoma, the Lawrence Livermore National Laboratory (LLNL), and the Lawrence Berkeley National Laboratory. Work at LLNL was conducted under the auspices of DOE Contract DE-AC52-07NA27344 and Genomic Science Program award SCW1555. Sequencing data can be found on the SRA at the accession: PRJNA6896656.

\section{Compliance with ethical standards}

Conflict of interest The authors declare no competing interests.

Publisher's note Springer Nature remains neutral with regard to jurisdictional claims in published maps and institutional affiliations.

Open Access This article is licensed under a Creative Commons Attribution 4.0 International License, which permits use, sharing, adaptation, distribution and reproduction in any medium or format, as long as you give appropriate credit to the original author(s) and the source, provide a link to the Creative Commons license, and indicate if changes were made. The images or other third party material in this article are included in the article's Creative Commons license, unless indicated otherwise in a credit line to the material. If material is not included in the article's Creative Commons license and your intended use is not permitted by statutory regulation or exceeds the permitted use, you will need to obtain permission directly from the copyright holder. To view a copy of this license, visit http://creativecommons. org/licenses/by/4.0/.

\section{References}

1. Schubert SD, Suarez MJ, Pegion PJ, Koster RD, Bacmeister JT. On the cause of the 1930s Dust Bowl. Science. 2004;303:1855-9.

2. Worster D. Dust bowl: the Southern plains in the 1930s (Oklahoma and Kansas). Dust bowl South Plains 1930s (Oklahoma Kansas). Oxford University Press; 1982; p. 15-50.

3. Baumhardt LR. Dust Bowl Era. In: Encyclopedia of water science. New York: Marcel Dekker; 2003.

4. Gelfand I, Sahajpal R, Zhang X, Izaurralde RC, Gross KL, Robertson GP. Sustainable bioenergy production from marginal lands in the US Midwest. Nature. 2013:493;514-7.

5. Bouton JH. Molecular breeding of switchgrass for use as a biofuel crop. Curr Opin Genet Dev. 2007;6:553-8.

6. Bouton, J. Genetic improvement of bioenergy crops. In: Vermerris W editors. Springer Science and Business Media; 2008. p. 295-308.

7. Milbrandt AR, Heimiller DM, Perry AD, Field CB. Renewable energy potential on marginal lands in the United States. Renew Sustain Energy Rev. 2014;29:473-81.

8. Stoof CR, Richards BK, Woodbury PB, Fabio ES, Brumbach AR, Cherney J, et al. Untapped potential: opportunities and challenges for sustainable bioenergy production from marginal lands in the northeast USA. Bioenergy Res. 2015;8:482-501.

9. McLaughlin SB, Kszos LA. Development of switchgrass (Panicum virgatum) as a bioenergy feedstock in the United States. Biomass Bioenergy. 2005;28:515-35. 
10. Ditomaso JM, Barney JN, Mann JJ, Kyser G. For switchgrass cultivated as biofuel in California, invasiveness limited by several steps. Calif. Agric. 2013;67:96-103.

11. Tilman D, Hill J, Lehman C. Carbon-negative biofuels from lowinput high-diversity grassland biomass. Science. 2006;314:15981600.

12. Ma Z, Wood CW, Bransby DI. Soil management impacts on soil carbon sequestration by switchgrass. Biomass Bioenergy. 2000;18:469-77.

13. Slessarev EW, Nuccio EE, McFarlane KJ, Ramon CE, Saha M, Firestone MK, et al. Quantifying the effects of switchgrass (Panicum virgatum) on deep organic $\mathrm{C}$ stocks using natural abundance $14 \mathrm{C}$ in three marginal soils. GCB Bioenergy. 2020;12:834-47.

14. Anderson-Teixeria KJ, Davis SC, Masters MD, Delucia EH. Changes in soil organic carbon under biofuel crops. GCB Bioenergy. 2009;1:75-96.

15. Barney JN, Mann JJ, Kyser GB, Blumwald E, Van Deynze A, DiTomaso JM Tolerance of switchgrass to extreme soil moisture stress: Ecological implications. Plant Sci. 2009;177:724-32.

16. Tiemann LK, Grandy AS. Mechanisms of soil carbon accrual and storage in bioenergy cropping systems. GCB Bioenergy. 2015;7:161-74.

17. Sher Y, Baker NR, Herman D, Fossum C, Hale L, Zhang X, et al. Microbial extracellular polysaccharide production and aggregate stability controlled by switchgrass (Panicum virgatum) root biomass and soil water potential. Soil Biol Biochem. 2020;143:107907.

18. Liebig MA, Schmer MR, Vogel KP, Mitchell RB. Soil carbon storage by switchgrass grown for bioenergy. Bioenergy Res. 2008;1:215-22.

19. Zan CS, Fyles JW, Girouard P, Samson RA. Carbon sequestration in perennial bioenergy, annual corn and uncultivated systems in southern Quebec. Agric Ecosyst Environ. 2001;86:135-44.

20. Frank AB, Berdahl JD, Hanson JD, Liebig MA, Johnson HA. Biomass and carbon partitioning in switchgrass. Crop Sci. 2004;44:1391-6.

21. Dabney SM, Shields FD, Temple DM, Langendoen EJ. Erosion processes in gullies modified by establishing grass hedges. Trans Am Soc Agric Eng. 2004;47:1561-71.

22. Cheng W, Parton WJ, Gonzalez-Meler MA, Phillips R, Asao S, Mcnickle GG, et al. Synthesis and modeling perspectives of rhizosphere priming. New Phytol. 2014;201:31-44.

23. Ashiq MW, Bazrgar AB, Fei H, Coleman B, Vessey K, Gordon A, et al. A nutrient-based sustainability assessment of purpose-grown poplar and switchgrass biomass production systems established on marginal lands in Canada. Can J Plant Sci. 2017;98:255-66.

24. Fontaine S, Barot S, Barré P, Bdioui N, Mary B, Rumpel C. Stability of organic carbon in deep soil layers controlled by fresh carbon supply. Nature. 2007;450:277-80.

25. Shahzad T, Rashid MI, Maire V, Barot S, Perveen N, Alvarez G, et al. Root penetration in deep soil layers stimulates mineralization of millennia-old organic carbon. Soil Biol Biochem. 2018;124:150-60.

26. Torn MS, Trumbore SE, Chadwick OA, Vitousek PM, Hendricks DM Mineral control of soil organic carbon storage and turnover. Nature. 1997;389:170-3.

27. Poeplau C, Helfrich M, Dechow R, Szoboszlay M, Tebbe CC, Don A, et al. Increased microbial anabolism contributes to soil carbon sequestration by mineral fertilization in temperate grasslands. Soil Biol Biochem. 2019;130:167-76.

28. Hestrin R, Lee MR, Whitaker BK, Pett-Ridge J. The switchgrass microbiome: a review of structure, function, and taxonomic distribution. Phytobiomes J. 2020;5:e-ISSN:2471-2906.

29. Lange M, Eisenhauer N, Sierra CA, Bessler H, Engels C, Griffiths RI, et al. Plant diversity increases soil microbial activity and soil carbon storage. Nat Commun. 2015:6;6707.
30. Ker K, Seguin P, Driscoll BT, Fyles JW, Smith DL Evidence for enhanced $\mathrm{N}$ availability during switchgrass establishment and seeding year production following inoculation with rhizosphere endophytes. Arch Agron Soil Sci. 2014;60:1553-63.

31. Clark RB, Baligar VC, Zobel RW. Response of mycorrhizal switchgrass to phosphorus fractions in acidic soil. Commun Soil Sci Plant Anal. 2005;36:1337-59.

32. Bahulikar RA, Torres-Jerez I, Worley E, Craven K, Udvardi MK. Diversity of nitrogen-fixing bacteria associated with switchgrass in the native tallgrass prairie of Northern Oklahoma. Appl Environ Microbiol. 2014;80:5636-43

33. Ghimire SR, Charlton ND, Craven KD. The mycorrhizal fungus, sebacina vermifera, enhances seed germination and biomass production in switchgrass (Panicum virgatum $l$ ). Bioenergy Res. 2009;2:51-8.

34. Kim S, Lowman S, Hou G, Nowak J, Flinn B, Mei C. Growth promotion and colonization of switchgrass (Panicum virgatum) cv. alamo by bacterial endophyte burkholderia phytofirmans strain PsJN. Biotechnol Biofuels. 2012;5:37.

35. Ghimire SR, Craven KD. Enhancement of switchgrass (Panicum virgatum $L$.) biomass production under drought conditions by the ectomycorrhizal fungus Sebacina vermifera. Appl Environ Microbiol. 2011;77:19.

36. Mulkey VR, Owens VN, Lee DK. Management of switchgrassdominated conservation reserve program lands for biomass production in South Dakota. Crop Sci. 2006;46:712-20.

37. Lee DK, Doolittle JJ, Owens VN. Soil carbon dioxide fluxes in established switchgrass land managed for biomass production. Soil Biol Biochem. 2007;39:178-86.

38. Monti A, Barbanti L, Zatta A, Zegada-Lizarazu W. The contribution of switchgrass in reducing GHG emissions. GCB Bioenergy. 2012;4:420-34.

39. Robertson GP, Grace PR. Greenhouse gas fluxes in tropical and temperate agriculture: the need for a full-cost accounting of global warming potentials. Environ Dev Sustain. 2004;6:51-63.

40. Fritsche UR, Sims REH, Monti A. Direct and indirect land-use competition issues for energy crops and their sustainable production-an overview. Biofuels Bioprod Biorefining. 2010;4:692-704.

41. Lange M, Habekost M, Eisenhauer N, Roscher C, Bessler H, Engels $\mathrm{C}$, et al. Biotic and abiotic properties mediating plant diversity effects on soil microbial communities in an experimental grassland. PLOS ONE. 2014;9:e96182.

42. Thakur MP, Milcu A, Manning P, Niklaus PA, Roscher C, Power $\mathrm{S}$, et al. Plant diversity drives soil microbial biomass carbon in grasslands irrespective of global environmental change factors. Glob Chang Biol. 2015;21:4076-85.

43. Chen C, Chen HYH, Chen X, Huang Z. Meta-analysis shows positive effects of plant diversity on microbial biomass and respiration. Nat Commun. 2019;10:1332.

44. Prober SM, Leff JW, Bates ST, Borer ET, Firn J, Harpole WS, et al. Plant diversity predicts beta but not alpha diversity of soil microbes across grasslands worldwide. Ecol Lett. 2015;18:85-95.

45. Mao Y, Yannarell AC, Davis SC, Mackie RI. Impact of different bioenergy crops on $\mathrm{N}$-cycling bacterial and archaeal communities in soil. Environ Microbiol. 2013;15:928-42.

46. Liang T, Yang G, Ma Y, Yao Q, Ma Y, Ma H, et al. Seasonal dynamics of microbial diversity in the rhizosphere of Ulmus pumila L. var. sabulosa in a steppe desert area of Northern China. PeerJ. 2019;7:e7526.

47. Jesus E da C, Liang C, Quensen JF, Susilawati E, Jackson RD, et al. Influence of corn, switchgrass, and prairie cropping systems on soil microbial communities in the upper Midwest of the United States. GCB Bioenergy. 2016;8:481-94.

48. Frasier I, Noellemeyer E, Fernández R, Quiroga A. Direct field method for root biomass quantification in agroecosystems. MethodsX. 2016;3:513-9. 
49. Carter MR, Gregorich EG (Eds.) Soil Sampling and Methods of Analysis. CRC Press; 2007.

50. Sheldrick BH, Wang C. Particle-size distribution. In: Carter, MR editor. Soil sampling and methods of analysis, Canadian society of soil science; 1993. p. 499-511.

51. McLean, E. Soil $\mathrm{pH}$ and lime requirement. Methods of soil analysis. Part 2. Chemical and microbiological properties, American Society of Agronomy, Soil Science Society of America. 1982 ;

52. AOAC Official Method 972.43, Microchemical Determination of Carbon, Hydrogen, and Nitrogen, Automated Method, in Official Methods of Analysis of AOAC International, 16th ed. Chapter 12, pp. 5-6, AOAC International, Arlington, VA; 1997.

53. Nelson DW, Sommers LE. Total Carbon, Organic Carbon, and Organic Matter. Chapter 34, p 1001-6. JM Bigham et al. editors. Soil Science Society of America and America Society of Agronomy. Methods of Soil Analysis. Part 3. Chemical Methods-SSA Book Series no. 5. Madison, WI. 1996.

54. Sah RN, Miller RO. Spontaneous reaction for acid dissolution of biological tissues in closed vessels. Anal Chem. 1996;64: 230-3.

55. Diamond D. Phosphorus in soil extracts. QuikChem Method 10115-01-1-A. Lachat instruments, Milwaukee, WI. 1995.

56. Olsen SR, Sommers LE. Phosphorus. In: AL Page, et al. (eds.) Methods of soil analysis: Part 2. Chemical and microbiological properties p. 403-30. Agron. Mongr. 9. 2nd edition. ASA and SSA, Madison, WI; 1982.

57. Prokopy WR. Phopshorus in $0.5 \mathrm{M}$ sodium bicarbonate soil extracts. Milwaukee, WI: QuikChem Method 12-115-01-1-B. Lachat Instruments; 1995.

58. Bowman RA, Moir JO. Basics EDTA as an extractant for soil organic phosphorus. Soil Sci Soc Am J. 1993;57:1516-8.

59. McKeague J, Day J. Dithionite-and oxalate-extractable Fe and AL as aids in 577 differentiating various classes of soils. Can. J. Soil Sci. 1966;

60. Mehra OP and Jackson ML. Iron oxide remobal from soils and clays by a dithionite-citrate system buffered with sodium bicarbonate. In Clays and clay materials (pp. 317-27). Pergamon; 2013.

61. Christiansen JR, Outhwaite J, Smukler SM. Comparison of CO2, $\mathrm{CH} 4$ and $\mathrm{N} 2 \mathrm{O}$ soil-atmosphere exchange measured in static chambers with cavity ring-down spectroscopy and gas chromatography. Agric For Meteorol. 2015;

62. Zhou J, Bruns MA, Tiedje JM. DNA recovery from soils of diverse composition. Appl Environ Microbiol. 1996;62:31622.

63. Wu L, Wen C, Qin Y, Yin H, Tu Q, Van Nostrand JD, et al. Phasing amplicon sequencing on Illumina Miseq for robust environmental microbial community analysis. BMC Microbiol. 2015;15:125.

64. Zhang J, Kobert K, Flouri T, Stamatakis A. PEAR: a fast and accurate Illumina Paired-End reAd mergeR. Bioinformatics. 2014;30:614-20.

65. Kuczynski J, Stombaugh J, Walters WA, González A, Caporaso JG, Knight R. Using QIIME to analyze 16s rRNA gene sequences from microbial communities. Curr Protoc Microbiol. 2012, Chapter 10:Unit 10.7.

66. Edgar RC. Search and clustering orders of magnitude faster than BLAST. Bioinformatics. 2010;26:2460-1.

67. Edgar RC. UPARSE: highly accurate OTU sequences from microbial amplicon reads. Nat Methods. 2013;10:996-8.

68. Wang Q, Garrity GM, Tiedje JM, Cole JR. Naïve Bayesian classifier for rapid assignment of rRNA sequences into the new bacterial taxonomy. Appl Environ Microbiol. 2007;73:5261-7.
69. Katoh K. MAFFT: a novel method for rapid multiple sequence alignment based on fast Fourier transform. Nucleic Acids Res. 2002;30:3059-66.

70. Castresana J. Selection of conserved blocks from multiple alignments for their use in phylogenetic analysis. Mol Biol Evol. 2000; $17: 540-52$.

71. Price MN, Dehal PS, Arkin AP. Fasttree: computing large minimum evolution trees with profiles instead of a distance matrix. Mol Biol Evol. 2009;26:1641-50.

72. Caporaso JG, Kuczynski J, Stombaugh J, Bittinger K, Bushman FD, Costello EK, et al. QIIME allows analysis of high-throughput community sequencing data. Nat Methods. 2010;7:335-6.

73. R Core Team. R Core Team (2014). R: a language and environment for statistical computing. R Found Stat Comput Vienna, Austria 2014. http://wwwR-project.org/.

74. Wickham H. ggplot2: elegant graphics for data analysis. New York: Springer; 2009.

75. Bates D, Mächler M, Bolker BM, Walker SC. Fitting linear mixed-effects models using lme4. J Stat Softw. 2015;67:1-48.

76. Anderson MJ. Distance-based tests for homogeneity of multivariate dispersions. Biometrics. 2006;62:245-53.

77. Rosseel Y. Lavaan: an R package for structural equation modeling. J Stat Softw. 2012;48:1-36.

78. Dise NB. Methane emission from Minnesota peatlands: spatial and seasonal variability. Glob Biogeochem Cycles. 1993;7:12342.

79. Bartlett KB, Harriss RC. Review and assessment of methane emissions from wetlands. Chemosphere. 1993;26:261-20.

80. Abraha M, Gelfand I, Hamilton SK, Chen J, Robertson GP. Carbon debt of field-scale conservation reserve program grasslands converted to annual and perennial bioenergy crops. Environ Res Lett. 2019;14:024019.

81. Roley SS, Xue C, Hamilton SK, Tiedje JM, Robertson GP. Isotopic evidence for episodic nitrogen fixation in switchgrass (Panicum virgatum L.). Soil Biol Biochem. 2019;129:90-8.

82. Cline LC, Zak DR. Soil microbial communities are shaped by plant-driven changes in resource availability during secondary succession. Ecology. 2015;96:3374-85.

83. Leff JW, Jones SE, Prober SM, Barberán A, Borer ET, Firn JL, et al. Consistent responses of soil microbial communities to elevated nutrient inputs in grasslands across the globe. Proc Natl Acad Sci U S A. 2015;112:10967-72.

84. Kang H, Fahey TJ, Bae K, Fisk M, Sherman RE, Yanai RD, et al. Response of forest soil respiration to nutrient addition depends on site fertility. Biogeochemistry. 2016;127:113-24.

85. Wagai R, Brye KR, Gower ST, Norman JM, Bundy LG. Land use and environmental factors influencing soil surface $\mathrm{CO}_{2}$ flux and microbial biomass in natural and managed ecosystems in southern Wisconsin. Soil Biol Biochem. 1998;30:1501-9.

86. Saunois M, Stavert AR, Poulter B, Bousquet P, Canadell JG, Jackson RB, et al. The global methane budget 2000-2017. Earth Syst Sci Data Discuss. 2019;12:1561-23.

87. Jackson RB, Saunois M, Bousquet P, Canadell JG, Poulter B, Stavert AR, et al. Increasing anthropogenic methane emissions arise equally from agricultural and fossil fuel sources. Environ Res Lett. 2020;15:071002.

88. Stocker TF, Qin D, Plattner GK, Tignor MMB, Allen SK, Boschung J, et al. Climate change 2013 the physical science basis: working group I contribution to the fifth assessment report of the intergovernmental panel on climate change. Climate change 2013 the physical science basis: working group i contribution to the fifth assessment report of the intergovernmental panel on climate change. 2013. 